\title{
Reflections on Sex Equality Under Law
}

\author{
Catharine A. MacKinnon $\uparrow$
}

There is a wrong way of thinking that one has rights, and a wrong way of thinking that one has not any.

No woman had a voice in the design of the legal institutions that rule the social order under which women, as well as men, live. ${ }^{2}$ Nor was the condition of women taken into account or the interest of women as a sex represented. To Abigail Adams' plea to John Adams to "remember the ladies" in founding the United States, he replied, "We know better than to repeal our Masculine systems." ${ }^{3}$ Mostly, one senses, women as such were beneath notice at the

Copyright ${ }^{\circ} 1991$ by Catharine A. MacKinnon.

† Catharine A. Mackinnon is Professor of Law at the University of Michigan Law School.

This Article has benefited greatly from readings by Alex Aleinikoff, Susanne Baer, Karen E. Davis, Andrea Dworkin, Owen Fiss, Kent Harvey, Yale Kamisar, Rick Lempert, Janice Raymond, Deborah Rhode, Kim Scheppele, Ted Shaw, Anne E. Simon, Cass Sunstein, Peter Westen, and James B. White. The law librarians at Michigan, especially Barbara Vaccaro and her staff, supported the research persistently and creatively. Rita Rendell supported everything with tremendous resourcefulness and competence. The argument on sexual assault as a form of sex discrimination has been largely shaped in discussions with Andrea Dworkin over the years. More recently it has been focused in collaboration with Elizabeth Shilton and other colleagues at the Women's Legal Education and Action Fund (LEAF) in litigation in Canada. Cass Sunstein has thought I should write my argument on abortion for some years and never neglected an opportunity to bring it up. The approach to reproductive control as a sex equality issue has also grown with colleagues at LEAF through a series of cases and legislative testimony. I have tried to footnote distinctive language by others and to highlight arguments focused and formulated by LEAF's submissions. My attempts will necessarily fall short of giving adequate credit to a collective process. Discussions about reproductive rights with Christine Boyle, Christie Jefferson, Helena Orton, and Lynn Smith were particularly formative. This aspect of the work owes the most to Mary Eberts. Her brilliant insights, depth of mind, breadth of knowledge, incisive yet tactful legal formulations, and her courage and tenacity in bearing witness to the truth of women's lives are written all over these pages. LEAF, of course, endorses only the content of its own facta.

1. S. WEIL, 1 THE NOTEBOOKS OF SMONE WER 152 (A. Wills trans. 1956).

2. In the United States, many men were also excluded from the official founding process. African American men and women were considered property. Indigenous peoples were to be subdued rather than consulted. Non-property owners were not qualified to participate in most states. C. BEARD, AN ECONOMIC INTERPRETATION OF THE CONSTITUTION OF THE UNITED STATES 64-72 (1913) (state-by-state property requirements for delegates to Constitutional Convention).

3. 1 ADAMS FAMIIY CORRESPONDENCE 370, 382 (L. Butterfield ed. 1963) (original manuscript dated 1776). 
time. ${ }^{4}$ The political theory which formed the principled backdrop for the new American republic certainly did not encourage their visibility. Hobbes grounded natural equality in the ability to kill. ${ }^{5}$ Locke argued that whoever did not leave a regime consented to it. ${ }^{6}$ Rousseau once posited the primitive passions as "food, a female, and sleep." It seems unlikely that the female role then, any more than now, socially empowered women to defend themselves effectively, far less aggress, or that they had any place to go to escape male supremacy, even if they had the means of exit. And whatever need they conceived for "a female" probably went largely unfulfilled. Yet the applicability of these reigning conceptions of equality, consent, and human need to at least half the population went unquestioned as women-including those owned neither in marriage nor in slavery-were deemed in theory to be participants in the social compact, while most women in life were not allowed to sign a contract. ${ }^{8}$

Equality was not mentioned in the Constitution or the Bill of Rights. The constitutive mind felt no need to guarantee it explicitly. It was apparently neither structurally essential to government nor in danger of loss to the federal power being created. Women who were not slaves were counted as persons, without being mentioned, for purposes of apportionment; slaves of both sexes were explicitly counted as three-fifths of a person. ${ }^{9}$ The only purpose of counting either of them was to divide power among white men, who kept the vote, that primitive exercise of citizenship, to themselves. The exclusion of all women as such from the polity was so far a given that the absence of half the

4. Being beneath notice takes many forms, but often looks much like this English example from a century after the U.S. founding: "I pass over many sections punishing particular acts of violence to the person, and in particular the whole series of offenses relating to the abduction of women, rape, and other such crimes. Their history possesses no special interest and does not illustrate either our political or our social history." J. STEPHEN, 3 HISTORY OF THE CRIMINAL LAW OF ENGLAND 117-18 (1883).

5. T. HOBBES, LEVIATHAN 80-82 (Blackwell's Political Texts ed. 1946) (1651) (In the state of nature, "[n]ature hath made men so equal [that] when all is reckoned together, the difference between man, and man, is not so considerable ... . For as to the strength of body, the weakest has strength enough to kill the strongest ....". 1764).

6. J. LOCKE, THE SECOND TREATISE OF CTVIL GOVERNMENT 49-50 (T. Peardon ed. 1952) (6th ed.

7. J. RousseaU, THE SOCIAL CONTRACT AND DisCOURSES 210 (G. Cole trans. 1950) (1762). Lorenne Clark called my attention to this quotation.

8. B. BABCOCK, A. FREEDMAN, E. NORTON \& S. ROSS, SEX DISCRIMINATION AND THE LAW 592-99 (1975). See generally S. OKIN, WOMEN IN WESTERN POLITICAL THOUGHT (1980). For an insightful critique of the meaning of contractarianism for women, see C. PATEMAN, THE SEXUAL CONTRACT 7-8 (1988).

9. The enumeration clause reads:

Representatives and direct Taxes shall be apportioned among the several States which may be included within this Union, according to their respective Numbers, which shall be determined by adding to the whole Number of free Persons, including those bound to Service for a Term of Years, and excluding Indians not taxed, three fifths of all other Persons.

U.S. CoNST. art. I, \&2, cl. 3.

Modern historical accounts document that apportionment was based on census data for the entire white population. See, e.g., M. BALINSKI \& H. YOUNG, FAIR REPRESENTATION 7 (1982). L. SCHMECKEBIER, CONGRESSIONAL APPORTIONMENT 109 (1941), shows that "free white females including heads of families" and "all other free persons" were counted for apportionment purposes. 
population from the founding process was not seen as qualifying its legitimacy-a legitimacy claimed on behalf of "we, the people"10 no less.

One hundred years and a war among men over equality among men later, ${ }^{11}$ the Fourteenth Amendment guaranteed "equal protection of the laws." Racial inequality was its crucible, its paradigm, its target, and its subtext. Sex-based denials of equal rights were not covered. ${ }^{12}$ It is thus a misnomer to say that the Reconstruction Amendments gave Blacks even formal constitutional equality. To the extent gender inequality limited it—no woman could vote, for example-equality was reserved for Black men. ${ }^{13}$ Still one hundred years later, women in the meantime having extracted the franchise, ${ }^{14}$ sex discrimination in private employment was forbidden under federal law only in a last minute joking "us boys" attempt to defeat Title VII's prohibition on racial discrimination. Sex was added as a prohibited ground of discrimination when this attempt-

10. See, for example, the otherwise interesting treatment of this concept in Ackerman, The Storrs Lectures: Discovering the Constitution, 93 YALE LJJ. 1013, 1032-43 (1984). My point also mirrors Ackerman's in the sense that constitutional interpretation is about who "we, the people" are taken to be.

11. This characterization would have insulted those who fought for a larger principle, but the insult is done by history, not by this description of it.

12. The explicit language of section 2 of the Fourteenth Amendment limits the prohibition on denial or abridgement of the right to vote in federal elections to "male inhabitants" who are over twenty-one and citizens. The Senate Committee on the Right of Women to Vote reported to the Senate that "the right of female suffrage is inferentially denied by the second section of the fourteenth amendment.... It is evident, from this provision, that females are not regarded as belonging to the voting population of a State." S. REP. No. 21, 42d Cong., 2d Sess. 4 (1872), reprinted in THE RECONSTRUCTION AMENDMENTS' DEBATES 571, 572 (A. Avins $2 d$ ed. 1974). For a contemporaneous discussion of failed attempts to strike "male" from the Fourteenth Amendment, see E. STANTON, S. ANTHONY \& M. GAGE, 2 HISTORY OF WOMAN SUFFRAGE 90-151 (1882).

In debates on the ratification of the Fourteenth Amendment, congressional repudiations of the notion that it would guarantee women's rights centered on suffrage, with little consideration of whether section 1 would grant women equal protection of the laws in areas other than the vote. In the exchanges, Senator Howard claimed that Madison would have granted suffrage to the "whole negro population as a class." Senator Johnson asked whether Madison would have included women, given that he used the term "persons." Senator Howand responded, "I believe Mr. Madison was old enough and wise enough to take it for granted there was such a thing as the law of nature which has a certain influence even in political affairs, and that by that law women and children were not regarded as the equals of men." CONG. GLOBE, 39th Cong., 1st Sess. 2767 (1866). Another exchange occurred on the question of whether the Fourteenth Amendment could be used to invalidate laws that distinguished on the basis of sex and marital status. Senator Hale asked if the Amendment would affect the common legal distinction between the property rights of married women on the one hand and those of unmarried women and men on the other. Senator Stevens replied, "When a distinction is made between two married people or two femmes sole, then it is unequal legislation; but where all of the same class are dealt with in the same way then there is no pretense of inequality." Senator Hale noted the fallacy in this reasonable classification model: "[n]f that means you shall extend to one married woman the same protection you extend to another, and not the same you extend to unmarried women or men, then by parity of reasoning it will be sufficient if you extend to one negro the same rights you do to another, but not those you extend to a white man." CONG. GLOBE, 39th Cong., 1st Sess. 1064 (1866). Generally, those who spoke in favor of including women under the Fourteenth Amendment confined themselves to suffrage under section 2 and lost. Those few who imagined section 1 could apply to women seemed to be using that possibility as a rhetorical device to defeat the Amendment altogether. Once again, women were largely beneath notice. A paradoxical result is that, because few seriously contemplated that "equal protection of the laws" might apply to sex, the record contains surprisingly little direct repudiation of the notion.

13. It was not effectively delivered to Black men either and has not been to this day. See generally D. BELL, AND WE ARE NOT SAVED (1987) (analyzing why racial equality has eluded Black Americans).

14. U.S. CONST. amend. XTX. 
ed reductio ad absurdum failed and the law passed anyway..$^{15}$ Maybe the commitment to ending racial inequality was strong enough to survive the insult of adulteration; maybe the fear of what Black men would do if the law did not pass was stronger than the fear of what women would do if it did; maybe Congress was equally against both bases for discrimination on principle or in recognition of reality; maybe it glimpsed that race and sex inequality were inextricably interconnected, fundamentally and in the lives of many; maybe some even found women's humanity not laughable. ${ }^{16}$ There is evidence that protecting white women from discrimination based on sex appealed to some in light of the protection of Black women from discrimination based on race. ${ }^{17}$ This missed that sex discrimination affected Black as well as white women and that white women were already protected from racial discrimination by being white.

Whatever Congress saw in 1964, it was not until 1971 that the United States Supreme Court deigned to conclude that unequal treatment of women on the face of the law could violate the constitutional guarantee of equal protection of the laws. ${ }^{18}$ With the subsequent failure of ratification of the proposed federal Equal Rights Amendment, which would have prohibited states or the federal government from denying or abridging equality of rights "on account of sex,"19 this recognition has remained a matter of interpretation rather than a mandate of express constitutional dimension. Thus has the legal entitlement to sex equality, tenuous and limited when there at all, ranged from anathema to afterthought.

An account of sex inequality under law in the United States must begin with what white men have done and not done because they have created the problem and benefited from it, controlled access to addressing it, and stacked the deck against its solution..$^{20}$ Women, for their part, have registered dissent to secondclass citizenship to a surprising degree, given that they have been precluded from most means of effective resistance and excluded from many of its are-

15. 110 CONG. REC. 2577 (1964).

16. Later Congresses, with considerable supporting evidence, have shown that they are serious about combatting sex discrimination under Title VII. See, e.g., H.R. REP. No. 899, 92d Cong., 2d Sess., reprinted in 1972 U.S. CODE CONG. \& ADMIN. NEWS 2137 (report accompanying Equal Employment Opportunity Act of 1972).

17. 110 CONG. REC. 2578-80 (1964) (comments of Rep. Martha Griffiths (D-Mich.)).

18. Reed v. Reed, 404 U.S. 71 (1971).

19. H.R.J. Res. 208, 92d Cong., 1st Sess., 117 CONG. REC. 35,326 (1971). For an illuminating history of the ERA, see D. RHODE, JUSTICE AND GENDER 63-80 (1989).

20. Men who are not white have similar records in countries they run, but it remains to be seen what men of color would do with power in countries like the United States in which they have been kept subordinate on the basis of race. Some pivotal moments of progress in the law of sex equality have been produced by American judges who are Black men. See, e.g., Barnes v. Costle, 561 F.2d 983 (D.C. Cir. 1977) (Robinson, J.) (first time a Court of Appeals recognizes sexual harassment as sex discrimination); Priest v. Rotary, 98 F.R.D. 755 (N.D. Cal. 1983) (Henderson, J.) (leading case excluding victim's sexual history from sexual harassment trials); California Fed. Sav. \& Loan v. Guerra, 479 U.S. 272 (1987) (Marshall, J.) (state initiative mandating unpaid pregnancy leave consistent with Title VII). 
nas. ${ }^{21}$ Women have often refused to accept the premises, limits, and rules of the law written by male dominance while having little choice but to live under it. Given that the majority of women were and are poor and working class and many were slaves and are members of racial minorities, this is even more impressive.

That women have voluntarily engaged law at all is a triumph of determination over experience. It has not been an act of faith. Determined to leave a trace, to make sex equality ordinary, to live under social conditions that reflect and reinforce their aspirations rather than suppress or extinguish them, to live in respect and safety rather than indignity and terror, to redefine social standards in the image of their values, to participate fully in their own times, to save their own lives and those of generations to come, women have long demanded legal change as one vehicle for social change. ${ }^{22}$ Treacherous and uncertain and alien and slow, law has not been women's instrument of choice. Their view seems to be that law should not be let off the hook, is too powerful to be ignored, and is better than violence-if not by much.

In recent years, the contemporary movement among women for civil equality has created a new political practice and form of theory with major implications for law. ${ }^{23}$ The distinctive theory forged by this collective movement is a form of action carried out through words. It is deeply of the world: raw with women's blood, ragged with women's pain, shrill with women's screams. It does not elaborate yet more arcane abstractions of ideas building on ideas. It participates in reality: the reality of a fist in the face, not the concept of a fist in the face. It does not exist to mediate women's reality for male consumption. It exists to bear witness, to create consciousness, to make change. It is not, in a word, academic. ${ }^{24}$

Legal practice and legal scholarship have not, on the whole, led this movement but have attempted to respond to it. The initial transmutation of the feminist impulse into law lost a lot in translation, creating an approach that has not changed much to the present. Remaining largely within traditional legalism, early practice and scholarship tended to accept reigning legal assumptions and method: laws developed when women were not allowed to learn to read and write, far less vote, enunciated by a state built on the silence of women, predicated on a society in which women were chattel, literally or virtually. In these early legal forays, existing doctrine was largely accepted as given-with the

21. See, e.g., Bradwell v. Illinois, 83 U.S. 130 (1872) (exclusion of women from practice of law).

22. See, e.g., D. RHODE, supra note 19 (women's legal equality initiatives analyzed in context of social movements); Williams, On Being the Object of Property, 14 SIGNS 5 (1988).

23. See generally C. MACKINNON, TOWARD A FEMINIST THEORY OF THE STATE (1989).

24. Examples include works by Andrea Dworkin, OUR BLOOD (1976), PORNOGRAPHY: MEN POSSESSING WOMEN (1981), ICE AND FIRE (1986), INTERCOURSE (1987), LETTERS FROM A WAR ZONE (1988), and MERCY (1990); by Kate Millett, SEXUAL PolmTICS (1970) and THE BASEMENT: MEDITATIONS ON A HUMAN SACRIFICE (1979); by Toni Morrison, THE BLUEST EYE (1970) and BELOVED (1987); and works edited by Barbara Smith, BUT SOME OF US ARE BRAVE (1982) (with G. Hull and P. Scott) and HOME GIRLS: A BLACK FEMINIST ANTHOLOGY (1983). This is a vast literature to which no selection begins to do justice. 
not minor exception that it be applied to women. Creativity meant shoehorning reality into doctrine.

The first step in these legal attempts to advance women was to demand women's inclusion on the same terms as men. Laws that had provided "special protections" for women were to be avoided. ${ }^{25}$ The point was to apply existing law to women as if women were citizens-as if the doctrine was not gendered to women's disadvantage, as if the legal system had no sex, as if women were gender-neutral persons temporarily trapped by law in female bodies. The women's movement claimed women's control over their procreative lives from intercourse to child care. In legal translation, this became state nonintervention in reproductive decisions under the law of privacy. The women's movement demanded an end to the sexual plunder of rapists, meaning to include an end to intercourse under conditions of unequal power on the basis of sex. In legal translation, this became the argument that rape had nothing to do with sexuality or with women and must be considered a gender-neutral crime of violence like any other. ${ }^{26}$ The women's movement exposed and documented the exploitation and subordination of women by men economically, socially, culturally, sexually, and spiritually. Legal initiatives in the name of this movement called for an end to legal classifications on the basis of sex..$^{27}$

Equality, in this approach, merely had to be applied to women to be attained. Inequality consisted in not applying it. The content of the concept of equality itself was never questioned. As if there could be no other way of thinking about it, the courts adopted that content from Aristotle's axiom that equality meant treating likes alike and unlikes unalike, ${ }^{28}$ an approach embod-

25. Muller v. Oregon, 208 U.S. 412 (1908), which permitted hours restrictions in the workplace for women only, accompanied by demeaning rhetoric, was the formative trauma, the negative benchmark.

26. It was not only the lawyers. A significant segment of the women's movement made a version of this argument as well. Susan Brownmiller's AGADST OUR WIL: MEN, WOMEN, AND RAPE (1976) was widely adopted as the basis for gender-neutralizing rape statutes in the name of treating rape as a crime of violence and not of sex.

27. See, e.g., Brown, Emerson, Falk \& Freedman, The Equal Rights Amendment: A Constitutional Basis for Equal Rights for Women, 80 YALE L.J. 871 (1971).

28. ARISTOTLE, ETHICA NICHOMACHEA bk. V.3, 1131a, 1131b (W. Ross trans. 1925) (Things that are alike should be treated alike, while things that are unalike should be treated unalike in proportion to their unalikeness.). Without explicit reference to Aristotle, this approach was adopted very early in cases under the Fourteenth Amendment. In a challenge to a municipal ordinance prohibiting washing and ironing in public laundries during certain hours, the Supreme Court found that "[i]t is not legislation discriminating against any one. All persons engaged in the same business within it are treated alike .... Class legislation ... is prohibited, but legislation which . . . affects alike all persons similarly situated, is not within the amendment." Barbier v. Connolly, 113 U.S. 27, 30-32 (1885). In another case decided soon after, the Court found that state laws which differed in the number of peremptory challenges allowed to jurors in capital cases did not violate the Fourteenth Amendment: "It [the Fourteenth Amendment] merely requires that all persons subjected to such legislation [in each state] shall be treated alike, under like circumstances and conditions ...." Hayes v. Missouri, 120 U.S. 68, 71 (1887). These cases paved the way for the formulation which remains fundamentally unchanged and unchallenged to this day. See, e.g., Reed v. Reed, 404 U.S. 71, 76 (1971) (citing Royster Guano Co. v. Virginia, 253 U.S. 412, 415 (1920)). 
ied in the Constitution's "similarly situated" requirement, ${ }^{29}$ which under Title VII became the more tacit requirement of comparability..$^{30}$ Inequality is treating someone differently if one is the same, the same if one is different. Unquestioned is how difference is socially created or defined, who sets the point of reference for sameness, or the comparative empirical approach itself. Why should anyone have to be like white men to get what they have, given that white men do not have to be like anyone except each other to have it? Since men have defined women as different to the extent they are female, can women be entitled to equal treatment only to the extent they are not women? Why is equality as consistent with systematic advantage as with systematic disadvantage, so long as both correlate with differences? Wouldn't this support Hitler's Nuremberg laws? ${ }^{31}$ Why doesn't it matter if the differences are created by social inequality? Never mind that Aristotle defended slavery and lived in a society in which prostitution-the buying and selling of women for sex-thrived, and in which no women were citizens. ${ }^{32}$

Rather than designing an indigenous solution to the problem of sex inequality, the early feminist legal view was, implicitly, that if equality meant being the same as men-and being different from men meant either no rights at all or sex-based deprivation circumscribed and rigidified by inadequate and patronizing compensation-women would be the same as men. Embarrassments to this analysis such as pregnancy, insurance, women's schools, ${ }^{33}$ and womenonly prisons were minimized as unimportant or lone exceptions or problems to be treated under some other rubric. Sexual assault and reproductive control

29. See, e.g., Royster Guano, 253 U.S. at 415 ("[T] $]$ he classification must be reasonable, not arbitrary, and must rest upon some ground of difference having a fair and substantial relation to the object of the legislation, so that all persons similarly circumstanced shall be treated alike."); Tussman \& tenBroek, The Equal Protection of the Laws, 37 CALIF. L. REV. 341, 344 (1949).

30. General Elec. Co. v. Gilbert, 429 U.S. 125 (1976), is a pinnacle example of this approach.

31. Actually, this concept of equality was used with perfect logic by a Nazi author to justify hierarchy under the Third Reich: "Equality can only mean relative equality, where an equal is treated equally and an unequal is treated unequally." ("Gleichheit kann nur verhältnismäßige Gleichheit bedeuten, wo Gleiches gleich, Ungleiches ungleich behandelt wird.") G. WEIPPERT, DAS PRINZIP DER HIERARCHIE, cited in Prengel, Gleichheit versus Differenz-eine falsche Alternative im feministischen Diskurs, in DIFFEREN UND GLEICHHErr 120, 121 (1990) (translated by author with Susanne Baer). (In German, one word, "Gleichheit," means both equality and sameness or identity, so the second clause could as well be translated: "where like is treated alike and unlike unalike.") The fascist implications of this approach-which readily rationalizes treating Jews one way and Aryans another-are embodied in a legend over the entrance to an extermination camp: "Jedem das Seine," translatable as, "To everyone what he deserves," or, "Each gets theirs." See Prengel, supra, at 121.

32. For a superb analysis of the status and treatment of women in ancient Greece, see E. KEULS, THE REIGN OF THE PHALLUS (1985), especially at 6, 30, 98, 108-09 (even women who were not slaves were virtually chattel) and 99, 187-203, 299, 327 (prostitution flourished). For discussion of Aristotle's treatment of slavery and the status of women, see E. SPELMAN, INESSENTIAL WOMAN 37-56 (1988).

33. See T. Butler, Pregnancy and Sex Equality: A "Unique Problem for Women?" 1-4 (Mar. 25, 1990) (unpublished paper presented at Twenty-first National Conference on Women and the Law, on file with author) (criticizing exclusion of these issues together with military combat and homosexual rights from ERA's strategy). 
were not considered legal issues of sex inequality at all, not in the doctrinal sense. ${ }^{34}$

The essentially assimilationist approach fundamental to this legal equality doctrine-be like us and we will treat you like we treat each other-was adopted in sex cases wholesale from the cases on racial discrimination. The judicial interpretation of sex equality, like its predicates the Fourteenth Amendment and Title VII, has been built on the racial analogy. So not only must women be like men, sexism must be like racism, or nothing can be done. ${ }^{35}$ Where the analogy seems to work, that is, where the sexes are reasonably fungible and the inequalities can be seen to function similarly-as in some elite employment situations, for example-equality law can work for sex. Where the sexes are different, and sexism does not readily appear to work like racismas with sexual abuse and reproductive control, for example-discrimination as

34. An early and innovative sex discrimination casebook, B. BABCOCK, A. FREEDMAN, E. NORTON \& S. Ross, supra note 8, at 975-90, for example, discussed abortion prohibitions on the premise that they revealed sex discrimination in society and the law's response to it. The law against sex discrimination as such was not discussed in terms of its possible application to abortion. Legally this distinction was exactly accurate.

In early litigation on abortion rights, sex equality claims were sometimes included among the initial grounds for women's right to abortion, but were dropped. One of the first initiatives against criminal abortion laws, colloquially called Women $v$. Connecticut, for example, contained an allegation that the abortion prohibition discriminated against women on the basis of sex. See Abele v. Markle, 452 F.2d 1121, 1123 (2d Cir. 1971) (discussing plaintiffs' initial claims). This claim does not seem to have been pursued at later stages in the litigation. A three-judge district court eventually declared Connecticut's anti-abortion laws to be unconstitutional on other grounds. Abele v. Markle, 342 F. Supp. 800 (D. Conn. 1972), vacated for reconsideration of mootness, 410 U.S. 951, on remand, 369 F. Supp. 807 (D. Conn. 1973) (finding case not moot and reaffirming consitutional holding).

In Roe $v$. Wade, the first amended complaint pleaded an equal protection violation, but this did not, apparently, refer to sex discrimination, and was not pursued. First Amended Complaint at IV, I 5, Roe v. Wade, 314 F. Supp. 1217 (N.D. Tex. 1970) (No. CA-3-3690-B) (on file with author), aff'd in part and rev'd in part, 410 U.S. 113 (1973). One amicus brief in Roe at the Supreme Court level squarely argued that the criminal abortion statutes at issue "violate the most basic Constitutional rights of women" because women bear "the disproportionate share of the de jure and de facto burdens and penalties of pregnancy, child birth and child rearing. Thus any statute which denies a woman the right to determine whether she will bear those burdens denies her the equal protection of the laws." Brief Amicus Curiae on Behalf of New Women Lawyers, Women's Health and Abortion Project, Inc., National Abortion Action Coalition at 6, Roe v. Wade, 410 U.S. 113 (1973) (No. 70-18) (on file with author). This brief assumed that while sexual intercourse was equal, its consequences were not: "Man and woman have equal responsibility for the act of sexual intercourse. Should the woman accidentally become pregnant against her will, however, she endures in many instances the entire burden or "punishment." Id. at 26. "And it is not sufficient to say that the woman 'chose' to have sexual intercourse, for she did not choose to become pregnant." Id. at 31 .

In Harris v. McRae, the Medicaid abortion funding case, only one amicus brief mentioned sex discrimination, and that was to point out that since women are socially discriminated against on the basis of sex, denying them abortions is an additional hardship. Brief Amicus Curiae for NOW, et. al. at 44, Harris v. McRae, 448 U.S. 297 (1980) (No. 79-1268) (on file with author). This brief did not make the legal argument that when the state does not pay for abortions, an act that hurts only women, they are denied equal protection of the laws on the basis of sex.

Most recently, in the litigation in Webster v. Reproductive Health Services, although several briefs discussed the importance of abortion for women's social equality, only one argued that denial of legal abortion constitutes sex discrimination in violation of equality law. Brief for the National Coalition Against Domestic Violence as Amicus Curiae Supporting Appellees at 5-25, Webster v. Reproductive Health Servs., 109 S. Ct. 3040 (1989) (No. 88-605) (on file with author) [hereinafter NCADV's Webster Brief].

35. Andrea Dworkin and I discuss this theme in Our PORNOGRAPHY AND CIVIL RIGHTS 11 (1988). 
a legal theory does not even come up. Along with these issues, the reality of inequality for those women for whom racism and sexism are too inseparable to be subject to a relation of analogy-those who are apparently too both to be regarded as fully either-has also been obscured.

The African American struggle for social equality has been the crucible for equality law in America. "That race and that emergency"36 has provided the deep structure, social resonance, and primary referent for legal equality, however abstractly phrased. Although racial equality has not been achieved, to say the least, law has periodically been induced to recognize some of the realities of white supremacy and has, at times, sustained these recognitions with results. ${ }^{37}$ Although the political analysis developed by the civil rights movement was substantive not abstract, self-respecting not comparative, and opposed hierarchical disadvantage rather than differentiation as such, courts in racial equality cases have largely confined themselves to the Aristotelian framework: qualification for admission into liberal humanity implicitly meant being like the white man. In Plessy v. Ferguson, for example, where segregation with equal facilities was held to be equality, the reason given was that Blacks were different from whites, so could be treated differently. ${ }^{38}$ When Brown v. Board of Education repudiated Plessy and held that educational segregation with equal facilities was inherently unequal, ${ }^{39}$ what changed was that Brown implicitly considered Blacks to be the same as whites. At least, Black school children were potentially so. This was a substantive shift in the political and ideological ground beneath the case law, not a pure doctrinal development. What was different was now the same. Difference could still justify differentiation, presumably including exclusion and subordination as well as segregation

36. Slaughter-House Cases, 83 U.S. (16 Wall.) 36, 81 (1873) (Miller, J., for the Court) ("We doubt very much whether any action of a State not directed by way of discrimination against the negroes as a class, or on account of their race, will ever be held to come within the purview of this provision [fifth section of the Fourteenth Amendment]. It is so clearly a provision for that race and that emergency, that a strong case would be necessary for its application to any other.").

37. Loving v. Virginia, 388 U.S. 1, 7 (1967) (invalidating antimiscegenation statutes as institutionalization of "White Supremacy"); Brown v. Board of Educ., 347 U.S. 483 (1954) (holding racially segregated public educational system inherently unequal); Swann v. Board of Educ., 402 U.S. 1 (1971) (neutrality may not be enough to overcome segregated school system; "affirmative action" may be required); Fullilove v. Klutznick, 448 U.S. 448 (1980) (upholding guarantee of federal funds for local public works projects to minority businesses). These results have been almost totally vitiated in Washington v. Davis, 426 U.S. 229 (1976) (proof of intent required in constitutional discrimination cases), Regents of the University of California v. Bakke, 438 U.S. 265 (1978) (white male invalidates affirmative action plan for disadvantaged groups), and City of Richmond v. J.A. Croson Co., 488 U.S. 469 (1989) (invalidating city contract preferences for minority businesses).

38. Plessy v. Ferguson, 163 U.S. 537, 551-52 (1896).

39. See Brown, 347 U.S. at 494 n.11 (citing K. CLARK, EFFECT OF PREJUdICE AND DISCRIMINATION IN PERSONALITY DEVELOPMENT (1950)). I deduce this conclusion from the Brown result, which mandates the same treatment, in the form of integration, for Black and white school children and from the Court's failure to conclude that Black children were "different" based on their "different" response to segregation. That is, unlike Plessy, the fact that segregation made Blacks feel inferior was not evidence that they were, but a measure of harm. They could only be harmed by being treated as inferior if they had already entered liberal humanity, or potentially could. This is not the same as saying that the Brown Court saw Blacks as equal to whites. 
(maybe even affirmative action). Being the same as the dominant group remained the equality test.

The insult to Black culture inherent in the view that to be different is to be inferior, meaning properly outside the reach of guarantees of equal treatment, is an assumption that lies coiled like a snake in Brown's ringing axiom that separate but equal is inherently unequal. This has been overlooked for the most part in the name of the benefits of integration, perhaps on the pragmatic consideration that separate Black schools were less likely to be equal to schools also attended by whites in a white supremacist society. ${ }^{40}$ That the failure to end discrimination by whites against Blacks may signal a defect in the whole approach, rather than merely its inadequate delivery, is suggested by the Court's current deinstitutionalization of racial equality, flawlessly predicated as it is on earlier progressive precedents. ${ }^{41}$ What did it also undoes it; differences, including products of social inequality, make unequal treatment not unequal at all. ${ }^{42}$

As a further illustration, legal initiatives for sovereignty by indigenous peoples presumably do not complain of inequality because no attempt is made to meet the white man's standard or to be compensated for not meeting it. Yet in seeking an end to nonrecognition as nations, indigenous peoples may be seen to claim another kind of equality: that of meeting their own standards, as other cultures recognized as nations meet theirs. Nationhood is a concept defined, ostensively at least, by those included in it, not in any state of nature. Seeking recognition through inclusion within that concept affirms a particularity which being the same as any other nation would efface, yet also asserts a right of place within the concept that is no different from any other nation. Legal recognition as sovereign is thus based on neither correspondence nor distinction, but on an equal entitlement to self-determination. Yet such an argument is not regarded as an equality argument because it is predicated upon neither sameness nor difference.

Whatever the defects of the Aristotelian model when applied to race and nation-and they are substantial-it is stunningly inappropriate to sex. Society defines women as such according to differences from men: hence the sex difference, as gender is customarily termed. Then equality law tells women that they are entitled to equal treatment mainly to the degree they are the same as

40. Some Black communities are increasingly questioning integration as a strategy for equality. Commentators have recently noted, for example, that historically Black colleges and universities, although they enroll only $17 \%$ of all Black college students, graduate $34 \%$ of all Black college graduates. Page, $A$ Black Anti-integration Backlash, Chicago Tribune, Feb. 19, 1989, \& 4 (Perspective), at 3, col. 2; Jordan, Is Desegregation Working for Blacks?, Boston Globe, July 1, 1990, Focus section at 89.

41. City of Richmond v. J. A. Croson Co., 488 U.S. 469 (1989), is an especially stunning example of pouring new politics (here conservative) into old doctrinal bottles (here liberal). The decision reverses the result of earlier precedents but leaves the doctrine undisturbed.

42. Even the relevance of the so-called differences to the ends in view is often obscure. In Regents of the University of California y. Bakke, 438 U.S. 265 (1978), for example, the admission tests that were used to assess qualifications for medical school were presumed valid, rather than validated. There was no inquiry into whether the test scores, which were racially disparate, were relevant to the goal of providing skilled doctors. 
men. ${ }^{43}$ The inadequacy of the sameness/difference model, and its consequences for equality under law, are strikingly revealed by the law's treatment of women of color. Discriminated against on the basis of race and sex, interactively and synergistically, ${ }^{44}$ the situation of women of color should have been improved most under laws addressing both. Instead, the law seems to have them least in mind. First the doctrine had apoplexy trying to decide if their inequality was sex or race. When it faced the fact that it is both at once, women of color were sometimes regarded as different twice over: from the male standard of race and the white standard of sex. ${ }^{45}$ This reveals a racism in the law of sex and a sexism in the law of race. White women meet the white male standard as white, if not male, and men of color meet the white male standard as male, if not white. Although a good many women of color can meet any substantive standard around, women of color as such meet neither. This treatment of women of color serves to support the view that the implicit standard for equality is what white men value about themselves and each other-an irreducible minimum of which is often that you be one. ${ }^{46}$

Attempts to redress women's inequality through law have almost exclusively continued to adhere to the Aristotelian model rather than challenge it. ${ }^{47}$ In the older cases on sex, women as a group were legally seen as different from men to the point of lacking legal personhood; thus, for example, in Bradwell $v$. Illinois, qualified women were not permitted to practice law under a rule that

43. This argument is elaborated and documented in chapter 12 of my TOWARD A FEMINIST THEORY OF THE STATE, supra note 23 (discussing sameness and difference as traditional equality theory).

44. Crenshaw, Demarginalizing the Intersection of Race and Sex: A Black Feminist Critique of Antidiscrimination Doctrine, Feminist Theory and Antiracist Politics, 1989 U. CHI. LEGAL F. 139, 141-50; Scales-Trent, Black Women and the Constitution: Finding Our Place, Asserting Our Rights, 24 HARV. C.R.-C.L. L. REV. 9 (1989); Note, Conceptualizing Black Women's Employment Experiences, 98 YALE L.J. 1457 (1989); P. Smith, Justice Denied: Black Women and the Search for Equality under Title VII (1990) (M.A. thesis, Yale University, on file with author); see also Matsuda, When the First Quail Calls: Multiple Consciousness as Jurisprudential Method, 11 WOMEN's RTS. L. REP. 7 (1989)

45. DeGraffenreid v. General Motors Assembly Div., 413 F. Supp. 142 (E.D. Mo. 1970), aff' $d$ in part and rev'd in part, 558 F.2d 480 (8th Cir. 1977); Jeffries v. Harris County Community Action Ass'n, 425 F. Supp. 1208 (S.D.Tex. 1977), aff' $d$ in part and vacated in part, 615 F.2d 1025 (5th Cir. 1980); see also Judge v. Marsh, 649 F. Supp. 770 (D.D.C. 1986) (Title VII plaintiff must pick one primary category of protected discrimination which is directed against a group sharing another protected characteristic).

46. Fortunately, this is not now the leading legal view. Hicks v. Gates Rubber Co., 833 F.2d 1406, 1416 (10th Cir. 1987) (in Title VII case brought by Black woman, evidence of racial and sexual harassment may be "aggregated"); Jeffries v. Harris County Community Action Ass'n, 615 F.2d 1025, 1032 (5th Cir. 1980) (Black woman may plead combined race and sex discrimination under Tite VII). While this recognition is an improvement, if the law protected people, not categories, from historic subordination, not misclassification, this solution would not have been necessary.

47. Partial exceptions are legal initiatives in the areas of sexual harassment, comparable worth, and pornography. Of these, only sexual harassment has succeeded in the courts to date. See, e.g., Meritor Sav. Bank v. Vinson, 477 U.S. 57 (1986) (sexual harassment actionable as sex discrimination); AFSCME v. Washington, 578 F. Supp. 846 (W.D. Wash. 1983) (comparable worth argument accepted as equality claim), rev'd, 770 F.2d 1401 (9th Cir. 1985). In American Booksellers Association v. Hudnut, 771 F.2d 323 (7th Cir. 1985), aff' $d$, 475 U.S. 1001 (1986), an ordinance making pornography actionable as sex discrimination on an equality theory relying on neither sameness nor difference was invalidated on First Amendment grounds. 
admitted qualified "persons" to the bar. ${ }^{48}$ The Court in the meantime having recognized that facial sex classifications may violate the equal protection clause, women were given the chance to meet the male standard in some cases. In Reed v. Reed ${ }^{49}$ for example, the Court invalidated facial statutory preferences for men, requiring that women be equally considered to administer estates. On this level, Reed is to Bradwell as Brown is to Plessy: women went from being categorically different to being putatively the same. Such a recognition looks like progress when it enables one to enter liberal humanity. But having to be the same as men to be treated equally remains the standard..$^{50}$

So stress on sameness has shaped litigation strategies-which not surprisingly have often found male plaintiffs their ideal vehicle ${ }^{51}$-and provided the dominant interpretation and political strategy of the ERA. ${ }^{52}$ The operative view has been that if classifications that distinguish by sex were eliminated from law, sex equality would be achieved. Some progress, largely but not totally ${ }^{53}$ limited to elites, has been made in this way. Some compensation for sex differences, often termed "special protections," have also been won, but most arguably have been more ideologically denigrating than materially helpful. ${ }^{54}$ While some situations have been improved, the conditions of inequality that made compensation seem necessary have been altered virtually not at all.

The harm of sex discrimination distinctively focused by this approach-the harm of facial classifications - has been largely the harm of stereotyping: assuming all women are the same and/or like some mythic feminine standard, and inherently and irredeemably different from men. To stereotype is to impose

48. Bradwell v. Illinois, 83 U.S. 130 (1872) (privileges or immunities clause does not compel women's admission to bar); In re Mabel P. French, (1905) 37 N.B.R. 359.

49. 404 U.S. 71 (1971). As I use this term, the male standard is also white and upper-class to a considerable extent, as evidenced by the fact that poor women of color do least well under it. That this standard, as applied to the situations being examined, is not ultimately about race and/or class but gender is suggested by its social meaning content and by the fact that women of the dominant race and/or class do not tend to do well under it either. It is accessible, to a degree, to men regardless of race or class, although it greatly helps men to be white and/or rich. It is also sex specific for men of color. Finally, it is of some interest that, as in Reed, the policies invalidated in most constitutional cases of sex discrimination brought by women involve preferences for men and detriments to women that lack express race or class specificity.

50. A current example is Price Waterhouse v. Hopkins, in which Ann Hopkins was made partner in an accounting firm for meeting the male standard, a victory against holding her to a "femininity" standard. 490 U.S. 228 (1989) (sex discrimination through stereotyping played role in denial of partnership), on remand, 737 F. Supp. 1202 (D.D.C. 1990) (relief granted includes making plaintiff a partner). The victory lies in the recognition of women's merits when they meet the male standard. The limits lie in the failure to recognize that the standard is a male one.

51. Cole, Strategies of Difference: Litigating for Women's Rights in a Man's World, 2 LAW \& INEQUALITY 33, 34 n.4 (1984) (collecting cases).

52. See MacKinnon, Unthinking ERA Thinking (Book Review), 54 U. CHI. L. REV. 759 (1987), for further discussion.

53. See, e.g., Califano v. Webster, 430 U.S. 313 (1977) (provision of Social Security Act allowing women to eliminate more low-earning years than men in calculating their retirement benefits compensates them for past discrimination).

54. Kahn v. Shevin, 416 U.S. 351 (1974) (upholding statute giving $\$ 500$ tax exemption to widows but not widowers); Schlesinger v. Ballard, 419 U.S. 498 (1975) (upholding statutory scheme giving women naval officers longer to be promoted than men before being discharged for lack of promotion). 
a trait or characterization that may be true of some members of a group upon all in the group. As an account of the injury of discrimination, this notion of misrepresentation by generalization is certainly partial, limited, can be trivializing and even perverse. What if the stereotype-such as women enjoy rape-is not really true of anyone? What if, to the extent a stereotype is accurate, it is a product of abuse, like passivity, or a survival strategy, like manipulativeness? What if, to the degree it is real, it signals an imposed reality, like a woman's place is in the home? What if the stereotype is ideologically injurious but materially helpful, like maternal preference in child custody cases? What if a stereotype is injurious as a basis for policy whether or not accurate, such as the view that women are not interested in jobs with higher salaries? Further, why is it an injury to be considered a member of a group of which one is, in fact, a member? Is the injury perhaps more how that group is actually treated? If sex-based generalizations are the problem of sex inequality under law, what can be done by law about those problems women generally do share? Will a law shaped to correct illusions rather than to confront the problems women have as women be able to face realities to the extent women have women's problems? If facial classifications are eliminated in the name of their exceptions, what becomes of those women the exceptions leave behind? This analysis suggests that the law of discrimination, to the extent it centers on empirical accuracy of classification and categorization, has targeted inequality's failures of perception such that full human variety is not recognized, above inequality's imposition of commonalities, such that full human variety is not permitted to exist.

As this doctrine developed, a grassroots practice of women's resistance to male dominance also developed, and with it a deeper confrontation with sex inequality. In rape crisis centers, battered women's shelters, incest support groups, and organizations of former prostitutes against prostitution, for example, nobody experiences anything so taxonomic and generic and neutral and analytic and abstract and empty as sameness and difference. The experiences that brought women there are not encounters with "different treatment," equally dangerous whether protective or invidious. They meet few illusions except their hopes for a better life. Stereotypes that see them as victims are overtaken by the reality in which they are victimized. Women face violent husbands, abusive fathers, violated children with venereal diseases, little food and no money, no jobs, a home on a shoestring if that, rats, cold, drug dealers, pimps, and cops. They are battered and raped indistinguishably, prostituted by force of violence and economics inseparably, already mothers and pregnant again without once having wanted to be. They live every day with fear, boredom, humiliation, deprivation, desperation, and dependency with no one to depend upon. Whatever sameness they share with men is not working very well, nor are their differences the precious kind. Their screams of pain and terror are not generally 
valorized as a "different voice." 55 Their difference lies in being on the bottom. It is this hierarchy that defines whatever difference matters, not the other way around, and defeats even most dreams of common humanity. As to the dimension of femaleness along which this is lived, what happens seems less exactly "based on sex" than because they are women. Tolerance of their differences or abolishing sex as a legal category or getting law more accurately to reflect their individuality is not even a watered-down approximation of what they need. What they need is change: for men to stop hurting them and using them because they are women, and for everyone to stop letting them do it because they are men.

Grounded in this world, law for women moved from seeking access to an unchanged legal regime to developing a substantively critical grasp of its tools, toward reshaping the law so that women can use it. Through such efforts, battered women's normal survival response to years of assault has begun to be reflected in the law of self-defense, so that those situations in which women are most likely to need to kill to save themselves are beginning to shape doctrine. ${ }^{56}$ State by state, the law of rape is being expanded to include rape in marriage, so that some of the most common rapes in life become rapes in law. ${ }^{57}$ Some protection has been extended to women testifying as rape victims, shielding their sexual history so they do not become pornography in court. ${ }^{58}$ Abortion has been largely, if precariously, decriminalized. ${ }^{59}$ Statutes of limitations in cases of incestuous sexual abuse of children have begun to be extended. ${ }^{60}$ The law of the family has been confronted by practitioners and theorists alike as an enforcement of patriarchy, in an attempt to empower women in marital dissolutions and child custody disputes. ${ }^{61}$ Tort concepts of harm and measures of damages have been scrutinized from the standpoint of women's

55. See generally C. GLLIGAN, IN A DIFFERENT VOICE (1982).

56. State of Washington v. Wanrow, 88 Wash. 2d 221, 559 P.2d 548 (1977); Ibn-Tamas v. United States, 407 A.2d 626, 634 (D.C. 1979); State v. Kelly, 97 N.J. 178, 200, 478 A.2d 364, 375 (1984); State v. Norman, 89 N.C. App. 384, 394, 366 S.E.2d 586, 592 (1988). But cf. State v. Thomas, 66 Ohio St. 2d 518, 423 N.E.2d 137 (1981) (expert evidence on battered women's syndrome inadmissible). See generally L. WALKER, THE BATTERED WOMAN SYNDROME (1984).

57. See, e.g., New York v. Liberta, 64 N.Y.2d 152, 474 N.E.2d 567 (1984), cert. denied, 471 U.S. 1020 (1985); Warren v. State, 255 Ga. 151, 336 S.E.2d 221 (1985). These laws typically apply, however, only to women who are separated from their husbands rather than to the day-in, day-out rape experienced by many while in a marriage; they often also have express cohabitant exceptions. See generally D. RUSSELI, RAPE IN MARRIAGE (1990). This area is changing rapidly. See Annotation, Criminal Responsibility of Husband for Rape, or Assault to Commit Rape, on Wife, 24 A.L.R. 4th 105 (1983).

58. See FED. R. EVID. 412.

59. Roe v. Wade, 410 U.S. 113 (1973).

60. See, e.g., CAL. Civ. Proc. Code $\$ 340.1$ (West Supp. 1990); Petersen v. Bruen, 792 P.2d 18 (Nev. 1990); Jones v. Jones, 242 N.J. Super. 195, 576 A.2d 316 (1990); Hammer v. Hammer, 142 Wis. 2d 257, 418 N.W.2d 23 (Wis. Ct. App. 1987); see also Salten, Statutes of Limitations in Civil Incest Suits: Preserving the Victim's Remedy, 7 HARV. WOMEN's L.J. 189 (1984).

61. See, e.g., P. CHESLER, MOTHERs ON TRIAL (1986); Fineman, Dominant Discourse, Professional Language and Legal Change in Child Custody Decisionmaking, 101 HARV. L. REV. 727 (1988). 
situation, in an attempt to encompass women's injuries. ${ }^{62}$ The law of contract has been criticized for abstracting from gender by assuming an arm's length atomism in transactions, and for presupposing behaviors and forms of power that imagine and favor men over women. ${ }^{63}$ In these instances, women's legal initiatives have transformed inclusion into change. They have moved from a request to be permitted to play by the rules to an understanding that having no say in the rules means not being permitted to play the game. They have moved from the use of existing doctrine to a critical practice of reconstruction. They have begun to move from advancing within the gender hierarchy to subverting it.

Remarkably, sex equality doctrine has largely escaped this kind of critical scrutiny and pressure to reconsider its fundamental precepts. ${ }^{64}$ Some changes have been made. In some tension with the doctrinal substructure, for example, the law of sex discrimination has been interpreted to cover sexual harassment and amended to cover pregnancy. ${ }^{65}$ But the potentially larger implications of such initiatives-one involving sexual assault, the other involving reproduction-for basic sex equality law have been underestimated. If discrimination based on pregnancy is discrimination based on sex, one can be different in a way that perfectly tracks the gender line ${ }^{66}$ and still be entitled to equal treatment. And if female sexuality is regarded as discriminated against rather than different when women are sexually harassed, given that the line of distinction tracks both biology and sex roles, the law of equality has taken a long step beyond the "similarly situated" requirement. Although implicitly undermined

62. See, e.g., Thurman v. City of Torrington, 595 F. Supp. 1521 (D. Conn. 1984) (on motion to dismiss, failure of police as a matter of policy to protect women complaining of violence by intimate males violates equal protection); Bender, Feminist (Re)Torts: Thoughts on The Liability Crisis, Mass Torts, Power, and Responsibilities, 1990 DUKE L.J. 848. Recent legal scholarship has expanded on Thurman's implicit recognition that police nonenforcement of laws against domestic violence is discrimination against women as a matter of law. Note, Battered Women and the Equal Protection Clause: Will the Constitution Help Them When the Police Won't?, 95 YaLE L.J. 788 (1986); Case Comment, Gender Based Discrimination in Police Reluctance to Respond to Domestic Assault Complaints, 75 GEO. L.J. 667 (1986).

63. Dalton, An Essay in the Deconstruction of Contract Doctrine, 94 YALE L.J. 997, 1000-03 (1985); Frug, Re-reading Contracts: A Feminist Analysis of a Contracts Casebook, 34 AM. U.L. REV. 1065 (1985).

64. Exceptions include C. MACKINNON, SEXUAL HARASSMENT OF WORKING WOMEN (1979); Littleton, Reconstructing Sexual Equality, 75 CALIF. L. REV. 1279 (1987). There has been far deeper and more extensive criticism of the law of racial equality, although it stops short of challenging the "similarly situated" requirement as such. See, e.g., Freeman, Legitimizing Racial Discrimination Through Antidiscrimination Law: A Critical Review of Supreme Court Doctrine, 62 MINN. L. REv. 1049 (1978); Lawrence, The Id, the Ego, and Equal Protection: Reckoning with Unconscious Racism, 39 STAN. L. REV. 317 (1987); texts cited infra note 184.

65. Vinson v. Taylor, 753 F.2d 141 (D.C. Cir. 1985), aff'd sub. nom. Meritor Sav. Bank v. Vinson, 477 U.S. 57 (1986); California Fed. Sav. \& Loan Ass'n v. Guerra, 479 U.S. 272 (1987); Pregnancy Discrimination Act of 1978, 42 U.S.C. $\$ 2000 \mathrm{e}(\mathrm{k})(1982)$.

66. Meaning, all those who are pregnant, hence discriminated against, are of one sex, even though some of those who are not pregnant, hence not discriminated against, are also of that same sex. Note that this is no different from most cases of sex discrimination, in which not all women may be discriminated against by a policy or practice, but all or most of those who are, are women. 
in these ways, ${ }^{67}$ neither the "similarly situated" test, nor its statutory version, the comparability requirement, has been exposed as the doctrinal guise of dominance. I do not know of a single American case that has directly challenged them. ${ }^{68}$

As a consequence, legal sex equality theory has not been designed to address the substance of most lived sex inequality. At work, for example, most women do jobs that mostly women do. ${ }^{69}$ So long as the extremity of this segregation can implicitly be considered a sex difference-whether caused by God ${ }^{70}$ the nature of thingss ${ }^{71}$ history ${ }^{72}$ the market, ${ }^{73}$ Congress, ${ }^{74}$ or what women are "interested in"75_ sex equality law will be stymied in ending it. The worse the inequality is, the more like a difference it looks. Yet the connection is not often made that the same notion of difference underlies protectionism, rejection of the claim of comparable worth, refusal to address pregnancy as a discrimination issue, and the difficulty of proof in garden-variety sex discrimination cases, even ones in which huge hiring and promotional disparities exist. ${ }^{76}$ The more perfect the disparity, the more difficult the showing of discrimination, so long as the basis for disparity is not mythic but real. Until this model based on sameness and difference is rejected or cabined, sex equality law may find itself increasingly unable even to advance women into male preserves-defined as they are in terms of socially male values and biogra-

67. Although these changes occurred first under Title VII, and thus were statutory, not constitutional, it is under the Constitution that the "similarly situated" test was developed and has persisted. Pregnancy discrimination has not been recognized as sex discrimination under the Fourteenth Amendment, Geduldig v. Aiello, 417 U.S. 484 (1974), but sexual harassment has, see, e.g., King v. Board of Regents, 898 F.2d 533,537 (7th Cir. 1990) (environmental sexual harassment violates equal protection if it is intentional); Trautvetter v. Quick, 916 F.2d 1140, 1151 (7th Cir. 1990) (intentional sexual harassment violates equal protection if claimant shows discrimination was because of her status as a female and not because of characteristics of her gender which are personal to her).

68. This approach has been challenged in Canada. In Andrews v. Law Society of British Columbia, [1989] 1 S.C.R. 143, the Supreme Court of Canada, interpreting the new equality provision of The Canadian Charter of Rights and Freedoms (the Canadian constitution) unanimously rejected the "similarly situated" test as "seriously deficient" for producing equality, $i d$. at 166, and adopted the approach based on substantive historical disadvantage advanced here. In so doing, that Court noted that "the similarly situated test would have justified the formalistic separate but equal doctrine of Plessy v. Ferguson." Id; see also Regina v. Turpin, [1989] 1 S.C.R. 1296.

69. U.S. EQUAL EMPLOYMENT OPPORTUNITX COMM'N, JOB PATTERNS FOR MINORTIES AND WOMEN IN PRIVATE INDUSTRY - 1986, at 1 (1988) (occupational distribution by race and sex); COMPARABLE WORTH: NEW DIRECTIONS FOR RESEARCH 3 (H. Hartmann ed. 1985); COMPARABLE WORTH, PAY EQUITY, AND PUBLIC POLICY 32-39 (1988).

70. Bradwell v. Tllinois, 83 U.S. 130, 141 (1872).

71. Id. at 142; cf. Plessy v. Ferguson, 163 U.S. 537, 551 (1896).

72. Lemons v. Denver, 17 Fair Empl. Prac. Cas. (BNA) No. 906 (Apr. 17, 1978), aff d, 620 F.2d 228 (10th Cir.), cert. denied, 449 U.S. 888 (1980).

73. AFSCME v. Washington, 770 F.2d 1401, 1408 (9th Cir. 1985).

74. Rostker v. Goldberg, 453 U.S. 57, 72 (1982) (women "not similarly situated" for purposes of draft registration because Congress has excluded women from combat).

75. EEOC v. Sears, 628 F. Supp. 1264, 1305 (N.D. IIl. 1986), aff'd, 839 F.2d 302 (7th Cir. 1988).

76. EEOC v. Sears is the cardinal example. Mary Becker makes this connection in From Muller y. Oregon to Fetal Vulnerability Policies, 53 U. CHI. L. REV. 1219 (1986). 
phies 7 - for the same reason it cannot get courts to value women's work in spheres to which women remain confined. Such a law can prohibit holding women to feminine standards in the workplace but not holding them to masculine ones. ${ }^{78}$ Designed for the exceptional individual whose biography approximates the male one, this approach cannot touch the situation of most women, where the force of social inequality effectively precludes sex comparisons.

Because the "similarly situated" requirement continues to control access to equality claims, the laws of sexual assault and reproductive control-areas as crucial in the social construction of women's inferior status as they are laden with misogyny - have not been seen as amenable to constitutional sex equality attack. Comparatively few men are raped and no men are denied abortions; gender comparisons are therefore unavailable or strained. So sexuality and procreation become happy differences or unhappy differences but never imposed inequalities. The legal system's treatment of rape as illegal under law while overwhelmingly permitted in fact ${ }^{79}$ is thus not regarded as state action that discriminates on the basis of sex, nor is criminalizing or refusing to fund a medical procedure that only women need. First there must be similarly situated men with whom to compare. Men's comparative lack of sexual and reproductive violation is not visible as a lack because it is relatively unthinkable that men would be hurt in these ways. ${ }^{80}$ As a result, when sex inequality is most extreme-most victims of sexual assault with impunity and all those denied legal or funded abortions are women-it drops off the sex inequality map. These are the social practices of dominance which create the gender difference as we know it. When the "similarly situated" assumption is revealed as the white male standard in neutral disguise, the fist of dominance in the glove of equality, the continuity with Plessy and Bradwell beneath the victories of Brown and Reed, dominance essentialized as difference becomes first on the equality agenda rather than last.

77. See, e.g., EEOC v. Sears, 839 F.2d 302, 313 (7th Cir. 1988).

78. See, e.g., Price Waterhouse v. Hopkins, 490 U.S. 228 (1989).

79. See infra notes 107-10 and accompanying text.

80. For a lucid analysis of sexual assault of men by men, see Scott, Between Men and Women/Between Men and Men: Male Rape and Straight Man's Law, 1 STAN. J.L. GENDER \& SEX. ORIENT. (forthcoming 1991). 
it's not so good to be born a girl/sometimes.

Ntozake Shange ${ }^{81}$

Women don't get half as much rights as they ought to; we want more, and we will have it.

The inequality of women to men deserves a theory of its own. The status of women resembles other bases for inequality, but, like every inequality, is also particular and unique. Women's situation combines unequal pay with allocation to disrespected work; sexual targeting for rape, domestic battering, sexual abuse as children, and systematic sexual harassment; depersonalization, demeaned physical characteristics, and use in denigrating entertainment; deprivation of reproductive control and forced prostitution. ${ }^{83}$ These abuses have occurred, in one form or another, for a very long time in a context characterized by disenfranchisement, preclusion from property ownership, ownership and use as object, exclusion from public life, sex-based poverty, degraded sexuality, and a devaluation of women's human worth and contributions throughout society. Like other inequalities, but in its own way, the subordination of women is socially institutionalized, cumulatively and systematically shaping access to human dignity, respect, resources, physical security, credibility, membership in community, speech, and power. Composed of all its variations, the group women has a collective social history of disempowerment, exploitation, and

81. N. SHANGE, THREE PIECES 135 (1981).

82. As quoted in 1 E. STANTON, S. ANTHONY \& M. GAGE, supra note 12, at 568.

83. This description has the developed West primarily, but not exclusively, in mind. In other cultures, the specific means differ but the ends of sexualized inferiority are the same. For example, purdah, the style of veiling prevalent in India and Pakistan, completely swathes women in layers of veils, marking women as sexually disruptive social entities requiring control and public segregation. They are different, physically shameful, and owned by men. The practices of clitoridectomy and infibulation, common in some parts of Africa, inflict genital mutilation-ranging from incision to complete removal of the clitoris and labia-upon pre-adolescent girls. These ritualistic abuses inscribe and express genital hostility, filth, and sexual control. See L. SANDERSON, FEMALE GENITAL MUTILATION, EXCISION AND INFIBULATION: A BIBLIOGRAPHY (1986).

As to women's economic inequality in the United States, one finds that from the 1950's to the 1970's, the ratio of Black women's earnings to Black men's has narrowed from slightly over half to 75\%. For whites, it has widened. In 1955, white women earned two-thirds of men's earnings. In the mid-1960's through 1980, they earned less than $60 \%$. In 1982, white women's earnings were $62 \%$ of white men's, the highest since 1958. Among women, the gap between Blacks and whites narrowed considerably from 1955, when Black women earned about half of what white women earned, to 1982, when the difference was less than 10\%. R. SIMON \& J. LANDIS, THE CRIMES WOMEN COMMT, THE PUNISHMENTS THEY RECEIVE 35-37 (1991). Even as this paltry progress was made in women's income relative to men's, men's average income dropped. And as women's share of employment has increased, so has their share of poverty. While men who are poor tend to be unemployed, women who are poor tend to be working full time-many at marginal jobs after divorce. K. PHILLIPS, THE POLITICS OF RICH AND POOR 202-03 (1990). 
subordination extending to the present. ${ }^{84}$ To be treated like a women is to be disadvantaged in these ways as an incident of being assigned to the female sex. To speak of social treatment "as a woman" is thus not to invoke any universal essence or homogeneous generic or ideal type, but to refer to this diverse material reality of social meanings and practices such that to be a woman "is not yet the name of a way of being human." 85

In this context, the failure of the law of sex equality to address sexual abuse and reproductive exploitation stands out. The law typically considers these abuses, cardinal experiences of sex inequality, ${ }^{86}$ to be crimes or privacy violations, not acts of sex discrimination. Equality doctrine does not seem to fit them. Equality law privileges recognition of facial classifications, in which the group descriptor is the legal inequality, because such devices have enforced much racial inequality. For the most part, the laws of sexual assault and reproductive control do not mention women or men, not any more. Yet these laws are not exactly neutral with an adverse impact either, at least not in the usual sense. They are too gendered to be neutral, and any law on rape or pregnancy affects the sexes differentially, without necessarily being discriminatory.

Existing legal equality templates utterly fail to capture the particular way in which the legal system organizes its participation in the subordination of women. ${ }^{87}$ Consider whether the law of sex classifications has the same relation to the realities of women's subordination as the law of racial classifications has to the realities of racial subordination. Does a law preferring men as administrators of estates ${ }^{88}$ have the same relation to women's subjection as a law prescribing "white only" railway cars has to racial subordination? Does a law prohibiting eighteen- to twenty-year-old boys in Oklahoma from drinking 3.2\% beer while permitting it to girl $\mathrm{s}^{89}$ have the same relation to sex inequality as a law requiring Black children in Kansas to attend racially segregated schools has to racial inequality? I mention the two seminal sex discrimination cases to suggest that facial sex classifications may be relatively peripheral to women's

84. The Women's Legal Education and Action Fund of Canada advanced this description as the meaning of substantive inequality, a concretely based definition to be preferred to abstract differentiation. See Factum of the Women's Legal Education and Action Fund of Canada (LEAF) paras. 49-53, at 21-23, Andrews v. Law Society of British Columbia, [1989] I S.C.R. 143 (Nos. 19955, 19956). In Andrews, the Supreme Court of Canada adopted an interpretation of constitutional equality consistent with this substantive approach.

85. R. Rorty, Feminism and Pragmatism (Dec. 7, 1990) (unpublished paper delivered as Tanner Lecture at University of Michigan, on file with author) ('MacKinnon's central point, as I read her, is that 'a woman' is not yet the name of a way of being human ...."). Elizabeth Spelman completely misses this concrete meaning of the phrase "as a woman" in her critique of its use in feminism. See generally E. SPELMAN, supra note 32.

86. Andrea Dworkin provides a superb analysis of the joint role of sexual abuse and deprivation of reproductive control in women's politics in A. DWORKIN, RIGHT-WING WOMEN (1983).

87. They also leave out of account a good deal of racial subordination.

88. Reed v. Reed, 404 U.S. 71 (1971).

89. Craig v. Boren, 429 U.S. 190 (1976). 
inequality, including by law. For claims based on sex, what the constitutional inequality net is made to catch has always been relatively rare and is now virtually extinct, while sex inequality, including through law, remains predatory and flourishing.

Much sex inequality is successfully accomplished in society without express legal enforcement and legitimation. Yet the law is deeply implicated in it. Law actively engages in sex inequality by apparently prohibiting abuses it largely permits, like rape, and by hiding the deprivations it imposes beneath ostensibly gender-neutral terms, like abortion. In the areas of sexual assault and reproductive control specifically, these legal concepts have been designed and applied from the point of view of the accused rapist and the outsider/impregnator respectively, and in the absence of the point of view of the sexually assaulted or pregnant woman. Most of the sexual assaults women experience do not fit the legal model of the ideal violation. Most rapes are by familiars not strangers, by members of one's own ethnic group not others, at home not on the street.90 The notion of consent here, the law's line between intercourse and rape, is so passive that a dead body could satisfy it.91 The law of rape is designed so that rape is what somebody else does and what almost never happens: so that what is done all the time, presumably including by those who design and interpret and enforce the laws, can be done. ${ }^{92}$

Similarly, when convenient to do away with the consequences of sexual intercourse (meaning children), women get abortion rights. Women can have abortions so men can have sex. ${ }^{93}$ When not convenient, and for those men who seek to control women through controlling their children instead of through controlling their ability to have them, and for those women (such as women of color) for whom more drastic means are deemed more convenient, women

90. M. AMIR, FORCIBLE RAPE 44 (1971) finds that $90 \%$ of rapes are intraracial. The rapist is a stranger in only $17 \%$ of all incidents, but in $55 \%$ of those reported to police. D. RUSSELL, SEXUAL EXPLOITATION 96-97 (1984) [hereinafter D. RUSSELL, SEXUAL EXPLOTTATION]; see also D. RusSELL, supra note 57, at 66-67. A recent study for the Department of Justice shows that in rapes with one offender, 7 of every 10 white victims were raped by a white offender, and 8 of every 10 Black victims were raped by a Black offender. C. HARLOW, FEMALE VICTMMS OF VIOLENT CRME 10 (1991).

91. A. DWORKIN, INTERCOURSE 129 (1987) ("Consent in this world of fear is so passive that the woman consenting could be dead and sometimes is."); S. ESTRICH, REAL RAPE 29-41 (1987) (originally through resistance requirement, passive submission amounts to consent in law of rape); see also State v. Alston, 310 N.C. 399, 312 S.E.2d 470 (1984) (woman's passivity supports finding of insufficient force for rape conviction).

92. See C. MACKINNON, supra note 23 , at 171-83.

93. While women may actually have abortions for many reasons, the formulation in the text, which owes much to Elizabeth Shilton, is a systemic point about why abortions are permitted. As documentation, consider this pungent juxtaposition:

Juli Loesch, a self-styled "pro-life feminist" associated with Operation Rescue, says, "the idea [of abortion] is that a man can use a woman, vacuum her out, and she's ready to be used again[.]" A NOW chapter advises feminists involved with anti-choice men to "[c]ontrol his access to your body. 'Just say no' to more sex[.]" . . . Pro- and anti-choice women meet on common ground ....

Baer, Book Review, 52 J. POL. 1012 (1990) (citations omitted); see also A. DwORkIN, supra note 86, at 138-39. 
are deprived of procreative choice through sterilization abuse the law either actively promotes or fails to recognize or redress, ${ }^{94}$ forced obstetrical interventions the law permits, ${ }^{95}$ fetal rights the law defines against women's rights, ${ }^{96}$ and criminalized and unfunded and bureaucratically burdened abortions the law deems adequate. ${ }^{97}$ In this light, the theme of the laws of sexual assault and reproduction is male control of, access to, and use of women.

Women are sexually assaulted because they are women: not individually or at random, but on the basis of sex, because of their membership in a group defined by gender. ${ }^{98}$ Forty-four percent of women in the United States have been or will be victims of rape or attempted rape at least once in their lives. ${ }^{99}$ Women of color experience disproportionately high incidence rates. ${ }^{100}$ In one

94. "Compulsory sterilization for eugenic reasons was legal in Puerto Rico during the years 1937 to 1960 ... . The total number of people undergoing compulsory sterilization for such reasons in this period has not been estimated." H. PRESSER, STERIIIZATION AND FERTILITY DECLINE IN PUERTO RICO 6 n.2 (1973); see also 1937 P.R. Laws 267 (repealed 1960) (providing for involuntary sterilization under variety of circumstances); Madrigal v. Quilligan, No. CV 75-2057, slip op. (C.D. Cal. 1978) (unpublished) (refusing to recognize or remedy sterilization of Chicanas at U.S.C.-Los Angeles County Medical Center, allegedly without their knowledge or informed consent), cited in Velez-I., The Nonconsenting Sterilization of Mexican Women in Los Angeles, in TWICE A MINORITY: MEXICAN AMERICAN WOMEN 235, 242-46, 248 n.4 (M. Melville ed. 1980), aff d, 639 F.2d 789 (9th Cir. 1981). The experiences of the individual plaintiffs in Madrigal are further discussed in Hernandez, Chicanas and the Issue of Involuntary Sterilization: Reforms Needed to Protect Informed Consent, 3 CHICANO L. REV. 3, 4-9 (1976). Thirty-nine percent of married women are currently sterilized in Puerto Rico, some voluntarily. DEP'T OF INT'L ECONOMIC \& SOCIAL AFFAIRS, RECENT LEVELS AND TRENDS OF CONTRACEPTIVE USE AS ASSESSED IN 1983, at 32 (1984). Ramirez de Arellano and Seipp explain that "[w]hile it is difficult to prove that the choice made by thousands of Puerto Rican women [to be sterilized] was not voluntary, it can nevertheless be argued that this choice was conditioned and constrained by the surrounding social framework. Medical authority, eugenist ideology, machismo, restricted employment opportunities, and the lack of other birth control alternatives were all factors that limited women's options." A. RAMtREZ DE ARELLANO \& C. SEIPP, COLONIALISM, CATHOLICISM, AND CONTRACEPTION 144 (1983) (footnote omitted).

95. In re A.C., 533 A.2d 611 (D.C. 1987) (cesarean section ordered for terminally ill pregnant woman), reh's granted and judgment vacated, 539 A.2d 203 (D.C. 1988), on reh'g, 573 A.2d 1235 (D.C. 1990); Jefferson v. Griffin Spalding County Hosp. Auth., 247 Ga. 86, 274 S.E.2d 457 (1981) (pregnant woman ordered to submit to cesarean section); In re Jamaica Hosp., 128 Misc. 2d 1006, 491 N.Y.S.2d 898 (N.Y. Sup. Ct. 1985) (forced blood transfusion to pregnant woman ordered to save her life or that of unborn child); Raleigh Fitkin-Paul Morgan Memorial Hosp. v. Anderson, 42 N.J. 421, 201 A.2d 537, (same) cert. denied, 337 U.S. 985 (1964).

96. See cases cited infra note 130 .

.97. Bureaucratic burdens on abortions enacted by state legislatures include, in addition to prohibitions on public funding, prohibitions on abortions in public facilities, prohibitions on abortion counseling by public employees, elaborate viability determination provisions, parental consent and notification requirements for minor girls, and licensing and other regulation of abortion facilities. Greenberg, State Abortion Laws and the Webster Decision, STATE LEGIS. REP., Aug. 1989, at 7-9.

98. The following argument was developed in collaboration with colleagues at LEAF and argued in interventions before the Supreme Court of Canada, including in the Factum of The Women's Legal Education and Action Fund (LEAF), The Queen v. Canadian Newspapers Co., [1988] 2 S.C.R. 122 (No. 19298) (on file with author).

99. D. RUSSEL, SEXUAL EXPLOITATION, supra note 90, at 35.

100. The following percentages of women report being victimized at least once by rape or attempted rape: white (non-Jewish), 45\%; Jewish, 50\%; Black, 44\%; Latina, 30\%; Asian, 17\%; Filipina, 17\%; Native American, $55 \%$; other, $28 \%$. Note that these figures refer to the proportions of women victimized and say nothing of the number of times they were victimized. D. RUSSELL, SEXUAL EXPLOITATION, supra note 90, at 84; see also Wyatt, The Sexual Abuse of Afro-American and White-American Women in Childhood, 9 CHILD ABUSE \& NEGLECT 507 (1985) (57\% of African American women and 67\% of white American women report at least one incident of sexual abuse before age 18). 
random sample study, only $7.5 \%$ of American women reported encountering no sexual assault or harassment at any time in their lives. ${ }^{101}$ Females-adults and children-make up the overwhelming population of victims of sexual assault. The perpetrators are, overwhelmingly, men. Men do this to women and to girls, boys, and other men, in that order. Women hardly ever do this to men.

Sexual violation symbolizes and actualizes women's subordinate social status to men. It is both an indication and a practice of inequality between the sexes, specifically of the low status of women relative to men. Availability for aggressive intimate intrusion and use at will for pleasure by another defines who one is socially taken to be and constitutes an index of social worth. To be a means to the end of the sexual pleasure of one more powerful is, empirically, a degraded status and the female position. In social reality, rape and the fear of rape operate cross-culturally as a mechanism of terror to control women. To attempt to avoid it, women are constrained in moving about in the world and walk down the street with their eyes averted. ${ }^{102}$ Rape is an act of dominance over women that works systemically to maintain a gender-stratified society in which women occupy a disadvantaged status as the appropriate victims and targets of sexual aggression. ${ }^{103}$

Sexual aggression by men against women is normalized. In traditional gender roles, male sexuality embodies the role of aggressor, female sexuality the role of victim, and some degree of force is romanticized as acceptable. ${ }^{104}$ Sexual assaults frequently occur in the context of family life or everyday social events, often perpetrated by an assailant who is known to the victim. ${ }^{105}$ In one study, one-third of American men in the sample say they would rape a woman if assured they would not get caught. The figure climbs following exposure to commonly available aggressive pornography. ${ }^{106}$ Pornography, which sexualizes gender inequality, is a major institution of socialization into

101. Diana Russell made this calculation on her data base at my request.

102. M. GORDON \& S. RIGER, THE FEMALE FEAR (1989).

103. S. BROWNMILLE, supra note 26, at 15; Sanday, The Socio-Cultural Context of Rape: A CrossCultural Study, 37 J. SOC. IsSUES 5 (1981).

104. D. SCULLY, UNDERSTANDING SEXUAL VIOLENCE 47-50, 59-92 (1990) (rape as "normal deviance" for men); J. STOLTENBERG, REFUSING TO BE A MAN 15 (1989) (rape central to masculinity); Check \& Malamuth, An Empiricial Assessment of Some Feminist Hypotheses About Rape, 8 INT'L J. WOMEN'S STUD. 414 (1985) (rape and forced sex widespread and largely acceptable).

105. D. RUSSELL, supra note 57, at 64-68; see also P. SANDAY, FRATERNITY GANG RAPE (1990).

106. Malamuth, Rape Proclivity Among Males, 37 J. SOC. ISSUES 138 (1981); Malamuth \& Check, The Effects of Mass Media Exposure on Acceptance of Violence Against Women: A Field Experiment, 15 J. RES. PERSONALTY 436 (1981); Malamuth, Aggression Against Women: Cultural and Individual Causes, in PORNOGRAPHY AND SEXUAL AGGRESSION 22-23 (1984); Malamuth \& Check, The Effects of Aggressive Pornography on Beliefs in Rape Myths: Individual Differences, 19 J. RES. PERsONALITY 299 (1985); Check \& Guloien, Reported Proclivity for Coercive Sex Following Repeated Exposure to Sexually Violent Pornography, Nonviolent Dehumanizing Pornography, and Erotica, in PORNOGRAPHY: RESEARCH ADVANCES AND POLICY CONSIDERATIONS (1989); see also Linz, Exposure to Sexually Explicit Materials and Attitudes Toward Rape: A Comparison of Study Results, 26 J. SEX RES. 50 (1989); Russell, Pornography and Rape: A Causal Model, 9 POL. PSYCHOLOGY 41, 43-45 (1988). Pornography is also implicated in the domestic battering of women. Sommers \& Check, An Empirical Investigation of the Role of Pornography in the Verbal and Physical Abuse of Women, 2 VIOLENCE \& VICTMS 189 (1987). 
these roles. The evidence suggests that women are targeted for intimate assault because the degradation and violation and domination of women is eroticized, indeed defines the social meaning of female sexuality in societies of sex inequality. Sexual assault thus becomes a definitive act of sexualized power and masculinity under male supremacy.

Only a fraction of rapes is reported, the most frequently mentioned reason for nonreporting being fear of the criminal justice system. Women of color fear its racism particularly. Only a fraction of reported rapes is prosecuted. Many rapes are "unfounded," an active verb describing the police decision not to believe that a rape happened as reported. ${ }^{107}$ Only a fraction of prosecuted rapes results in convictions. Rape sentences are often short. Most rapists therefore continue to live in society either undetected or unpunished and unrehabilitated. In many instances, one must suppose that they remain unaware that they did anything even potentially culpable. ${ }^{108}$ Perhaps these data are viewed with complacency on the unconscious belief that sexual assault is inevitable or a constant that cannot be taken seriously because it is so common. Perhaps sexual assault would not be so common if it were taken seriously.

Seen in this way, sexual assault in the United States today resembles lynching prior to its recognition as a civil rights violation. It is a violent humiliation ritual with sexual elements in which the victims are often murdered. It could be done to members of powerful groups but hardly ever is. When it is done, it is as if it is what the victim is for; the whole target population cringes, withdraws, at once identifies and disidentifies in terror. The exemplary horror keeps the group smaller, quieter, more ingratiating. The legal system is dominated by members of the same group engaged in the aggression. The practice is formally illegal but seldom found to be against the law. The atrocity is de jure illegal but de facto permitted.

Unlike the law of murder, however, before the rape law is administered, it is biased on its face. ${ }^{109}$ Rape is typically defined as intercourse with force against one's will. Apparently this is not considered redundant, implying that women consent to sex with force all the time. Given this sadomasochistic definition of sex at the line between intercourse and rape, it is no wonder that the legal concept of consent can coexist with a lot of force. Crystallizing in doctrine a norm that animates the rape law more generally, the defense of "mistaken belief in consent" defines whether a rape occurred from the perspec-

107. S. ESTRICH, supra note 91, at 15-20 (1987) (summary of legal system's response to rape). In Oakland, California recently, after disclosure that 1 in 4 reported rapes and attempted rapes in 1989 were "unfounded" by the Oakland Police, an investigation revealed that 79 of the 112 alleged rapes reviewed did in fact occur. Police conceded that some victims, many of whom were "cocaine users, prostitutes, or acquainted with their assailants," were never interviewed by investigators after the initial report. Prosecution Seen as Unlikely in 228 Rape Cases in Oakland, N.Y. Times, Nov. 13, 1990, at B10, col. 1.

108. S. Smithyman, The Undetected Rapist (1978) (Ph.D. dissertation, Claremont Graduate School, on file with author).

109. See C. MACKnNoN, supra note 23 , at 171-83. 
tive of the accused rapist, not from the perspective of the victim or even based on a social standard of unacceptable force or of mutuality. ${ }^{110}$ To a degree unlike any other crime to the person, the credibility of the victim is the issue on which turns whether any harm was done. Only in sexual assault cases is it believed, against the victim's statement to the contrary, that she may have consented to forced acts against her. The view that women seek out and enjoy forced sex is pure special pleading for the accused. This is the perspective the law has taken.

A major exception in application has been accusations by white women of sexual assault by African American men-a relatively rare type of rape. ${ }^{111}$ Here the usual presumption that the woman consented turns to the opposite on racist grounds: because the man is Black, she could not have wanted it. The possibility exists that prosecutions under such conditions can be successful independent of whether a rape occurred or of whether the particular defendant was the perpetrator. At the same time, women of color, overwhelmingly the victims of the sexual assaults men of color do perpetrate, are often faced with the necessity of siding with men of color on grounds of community selfpreservation. Statistically, such a legal posture makes it more possible to convict when a sexual assault is less likely to have occurred, and next to impossible to convict when one is more likely to have occurred. It is not in women's interest to have men convicted of rape who did not do it, any more than it is in women's interest not to have men convicted of rape who did. Not only the law, but the credibility of women - that rare commodity-is undermined.

Women and men are not similarly situated with regard to sexual assault in the sense that they are not equally subject to it or equally subjected to it. But this is the inequality that indicts it, not the difference that exonerates it or exempts it from equality scrutiny. The one case in which the Supreme Court adjudicates the constitutionality of a sexual assault statute in the sex equality context misses this point entirely. Michael $M{ }^{112}$ challenges the California statutory rape law as sex-discriminatory because it makes only males criminals

110. D.P.P. v. Morgan, [1975] 2 W.L.R. 913, 2 All E.R. 347; Pappajohn v. The Queen, (1980) 111 D.L.R.3d 1; People v. Mayberry, 1S Cal. 3d 143, 542 P.2d 1337, 125 Cal. Rptr. 745 (1975).

111. Reporting rates may be higher for interracial rape of white women because white women may perceive they are more likely to be believed in such cases. LaFree, Male Power and Female Victimization: Toward a Theory of Interracial Rape, 88 AM. J. Soc. 311 (1982). In one study, Black men also appear to be slightly overrepresented in the stranger rape category. D. RUSSELL, SEXUAL EXPLOITATION, supra note 90, at 98-99. That the white male attention to this comparatively rare pattern in rape is a deadly obsession is supported by the fact that almost $90 \%$ of those executed for rape from 1930 to 1980 were Black men convicted for the rape of white women. Greenberg, Capital Punishment as a System, 91 YALE L.J. 908, 912 (1982).

112. Michael M. v. Superior Court of Sonoma County, 450 U.S. 464 (1981). Justice Blackmun wrote separately, adding a fifth vote to uphold the statute, but did not mention biology as a reason. He pointed out the tension between the plurality's recognition of sex equality issues in teenage pregnancy and their failure to see the same issues in the abortion context. Id. at $481-83$ (Blackmun, J., concurring in the judgment). 
for having sex with underage girls. The plurality upheld the statute on grounds that underage females could validly be protected from sex because they were likely to become pregnant. The dissent would have invalidated the statute, among other reasons, because it did not equally criminalize the two participants in the crime and because it embodied the invidious stereotype that men usually aggress in sex. The plurality opinion grasped the sex-differential reality at the cost of attributing it to biology. The dissent understood the reality of sexual assault of girls to be socially created rather than biological, at the cost of failing to understand it as nonetheless gender-based. The plurality saw a hierarchy but thought it was biologically fixed. The dissent saw the possibilities for change, but missed the hierarchy. The plurality allowed a sex difference-potential pregnancy - to render girls "not similarly situated" and to support a sex-differential statute that divides women by age. Never mind that many of those protected cannot become pregnant and more of those not protected can, that young boys are sexually assaulted too (usually by older males), and that girls do not lose their vulnerability to sexual coercion upon turning eighteen. The dissent revealed more concern with avoiding the stereotyping attendant to the ideological message the law communicated than with changing the facts that make the stereotype largely true. In the interest of opposing facial distinctions and debunking the supposed myth of male sexual aggression, the fact that it is overwhelmingly girls who are sexually victimized by older males for reasons wholly unrelated to their capacity to become pregnant was completely obscured. The facts of social inequality, of sex aggravated by age, that could have supported particular legislative attention to the sexual assault of girls were not even considered. Underage girls form a credible disadvantaged group for equal protection purposes when the social facts of sexual assault are faced, facts which prominently feature one-sided sexual aggression by older males. ${ }^{113} \mathrm{It}$ seems that in order to imagine equality, one must first be blind to inequality, and to see inequality blinds one to seeing that equality is possible.

Perhaps this case reveals the reason that the law of sexual assault has never been held to sex equality standards, at the same time as providing clues to the reason equality is defined in terms of sameness and difference in the first place. Sexuality, hence sexual assault, is believed by many to be biological, a natural part of the so-called sex difference. We are dealing here with the assumption that rape is inevitable in gendered biology. If explicitly embodied in law, such an assumption ought to violate equal protection of the laws. In fact, in Dothard v. Rawlinson, it has been found to be a nondiscriminatory reason for excluding women from some employment, equating capacity to be raped with membership

113. D. RUSSELL, SEXUAL EXPLOTTATION, supra note 90, at 184-85, 215-31; D. RUSSELL, THE SECRET TRAUMA 217, 222 (1986). Note that the majority of perpetrators in all cases of sexual abuse of girls have been found to be nonstranger nonrelatives, $i d$. at 219 , like the situation in the Michael $M$. case. 
in the female gender. ${ }^{114}$ What it comes down to is that the most extreme instances of sex inequality in society are considered sex differences, hence reasons equality law does not apply, as in Michael M., or reasons discrimination can be openly justified, as in Dothard. Men can be raped, and sometimes are. That alone should suggest that the overwhelming numbers of women in the rape victim population expresses inequality, not biology. Will rape have to be comparably common in and definitive of men's status before women can be found deprived of equal protection of the laws when they are raped with legal impunity? How much legal impunity will it take before the law of sexual assault-its terms, enforcement, nonenforcement, and interpretation-is recognized as sex discrimination?

Sexual assault, in this argument, has a special place in women's social status and the law of sexual assault has a distinctive place in the history of women's oppression by government. There is no lack of atrocities disclosing judicial bias by courts in sexual assault adjudications. ${ }^{115}$ Condescending, demeaning, hostile, humiliating, and indifferent judicial treatment of female victims of sexual assault is not uncommon. ${ }^{116}$ Government commits this inequality and should rectify it. Law has a choice. It can inscribe this misogyny on society yet more authoritatively, promoting sex inequality, or it can move against it by promoting sex equality. Sexual assault cannot be treated as gender neutral because sexual assault is not gender neutral. The law of sexual assault

114. Dothard v. Rawlinson, 433 U.S. 321, 336 (1977) (women's capacity to be raped, termed their "very womanhood," justifies state regulation disqualifying female employees from contact positions in men's prison). Male gender, then, constituted a bona fide occupational qualification (BFOQ) for the job. Thus does sexual assault define gender as such.

115. See generally JUDICIAL COUNCIL ADVISORY COMM. ON GENDER BIAS IN THE COURTS, ACHIEVING EQUAL JUSTICE FOR WOMEN AND MEN IN THE COURTS (Draft Report 1990) (California); NEW JERSEY SUPREME COURT TASK FORCE ON WOMEN IN THE COURTS, THE FIRST YEAR REPORT OF THE NEW JERSEY SUPREME COURT TASK FORCE ON WOMEN IN THE COURTS (1984); NEW JERSEY SUPREME COURT TASK FORCE ON WOMEN IN THE COURTS, THE SECOND REPORT OF THE NEW JERSEY TASK FORCE ON WOMEN IN THE COURTS (1986); Report of the New York Task Force on Women in the Courts, 15 FORDHAM URB. L.J. 11 (1986-87); see also Schafran, Documenting Gender Bias in the Courts: The Task Force Approach, 70 JUDICATURE 280 (1987). The California report documents that women victims, witnesses, and expert witnesses were generally perceived as less credible than men, and women lawyers as less competent. JUDICIAL COUNCL ADVISORY COMM. ON GENDER BIAS IN THE COURTS, supra, tab 4, at 59, 61. It also shows that legal areas which disproportionately affect women and children, such as family law, are allocated fewer court resources. Id. tab 5, at 82-93.

116. Recently cited in testimony by NOW before the Senate Judiciary Committee are the following cases, which could be picked virtually at random from a newspaper. In 1982, a Wisconsin judge called a five-year-old victim "'an unusually sexually promiscuous young lady." In 1987, another Wisconsin judge sentenced a defendant to only 90 days in jail for four felony sexual assault convictions involving two 15-year-old girls. In that case, the judge commented favorably on the defendant's appearance and personality at sentencing, stating he " could have had the pick of the flock; unfortunately he spread it around.' "In 1986, a Pennsylvania judge declared a defendant not guilty of attempted rape and aggravated assault despite a police witness to the attack, stating: "This was an unattractive girl and you are a good-looking fellow. You did something . . . stupid.'" Women and Violence: Hearing Before the Senate Comm. on the Judiciary on Legislation to Reduce the Growing Problem of Violent Crime Against Women, 101st Cong., 2d Sess. 66-67 (1990) (Statement of NOW Legal Defense and Education Fund). 
cannot be treated as private action because it is government action. ${ }^{117}$ Women are not receiving equal protection of the laws. The equal protection clause is inconsistent with state law that promotes sex inequality. The law of sexual assault commands Fourteenth Amendment scrutiny. ${ }^{118}$

Sexual assault is already seen as gendered in the Supreme Court's treatment of the statute in Michael $M$. as facial sex discrimination against men, apparently as a result of its use of the term "sexual intercourse." 119 Sexual assault is squarely understood as a form of sex discrimination in the recognition that sexual harassment, which can include sexual assault, is actionable sex-based discrimination. ${ }^{120}$ Just as women are sexually harassed based on their sex, women are sexually assaulted based on their sex. Both forms of treatment (which overlap) are categorical and group-based. Men, usually heterosexual, harass and rape women. ${ }^{121}$ Any woman within the ambit of such a man is his potential victim and, when she is harassed, is disadvantaged because of her sex. But for her sex, she would not be so treated. ${ }^{122}$ Similar to the way Title VII governs the workplace, the criminal law of sexual assault, governed by the Fourteenth Amendment, would set sex equality standards for society at large.

Deprivation of equal access to justice because one is a woman is deprivation of equal protection of the laws on the basis of sex. This analysis offers a constitutional basis for defending sexual history exclusions from fair trial attacks $^{123}$ and for upholding publication bans on names and identifying infor-

117. Obviously, action by states is state action. This traditionally includes state criminal statutes and their interpretation, as well as acts of government officials such as police. There are many legal nuances and constraints to the state action doctrine, but this facet of the argument raises none of them. See generally L. TRIBE, AMERICAN CONSTITUTIONAL LAW 1688-1720 (2d ed. 1988).

118. A pioneering attempt to advance this argument, in spite of its lack of questioning of equal protection doctrine and its acceptance of some biological arguments, is Berger, Man's Trial, Woman's Tribulation: Rape in the Courtroom, 77 CoLUM. L. REv. 1 (1977) (use of sexual conduct or reputation evidence to show consent violates Fourteenth Amendment sex equality). Supportive related arguments include Comment, Rape in Illinois: A Denial of Equal Protection, 8 J. MARsHALL J. PRAC. \& PROC. 457 (1975) (disparate evidentiary rules treating rape of vagina less favorably than forced anal or oral sex constitutes sex discrimination against women in violation of equal protection clause of Illinois Constitution); West, Equality Theory. Marital Rape, and the Promise of the Fourteenth Amendment, 42 FLA. L. REV. 45 (1990) (excluding married women from coverage by rape law denies equal protection).

119. "Section 261.5 defines unlawful sexual intercourse as 'an act of sexual intercourse accomplished with a female not the wife of the perpetrator, when the female is under the age of 18 years.' The statute thus makes men alone criminally liable for the act of sexual intercourse." Michael M. v. Superior Court, 450 U.S. 464, 464 (1981). Note that the statute does not mention men.

120. Meritor Sav. Bank v. Vinson, 477 U.S. 57 (1986).

121. It is also arguable that men who are raped (usually by men) are raped as men, as well as feminized in the process. Thus rape of men by men, and its unfavorable treatment by law, could also be seen as sex discrimination.

122. Bames v. Costle, 561 F.2d 983, 990 (D.C. Cir. 1977) ("[b]ut for her womanhood" plaintiff would not have been sexually harassed); $c f$. Orr v. Orr, 440 U.S. 268, 295 (1979) (Rehnquist, J., dissenting) ("but for his sex" test should be used to deny standing to man challenging law precluding alimony awards to men).

123. This argument would support the results, and likely a stronger statutory exclusion, in cases like People v. Blackburn, 56 Cal. App. 3d 685, 128 Cal. Rptr. 864 (1976) (upholding constitutionality of rape shield statute against fair trial attack), and People v. McKenna, 196 Colo. 367, 585 P.2d 275 (1978) (upholding rape shield statute against separation of powers and Sixth Amendment confrontation attack). The Women's Legal Education and Action Fund of Canada argues in Seaboyer v. The Queen and Gayme 
mation of sexual assault victims against First Amendment challenges. ${ }^{124}$ It supports a constitutional appeal whenever a court engages in judicial sexism in a sexual assault trial, a basis for massive civil litigation under federal civil rights statutes for nonenforcement and misenforcement of sexual assault laws on the basis of sex, and a foundation for challenging the facial unconstitutionality of biased state criminal laws that adopt a male perpetrator's point of view to the systematic disadvantage of female victims. It squarely supports legislation making sexual assault actionable as a form of sex discrimination. ${ }^{125}$

Usually, sex precedes reproduction. In part through its connections with forced sex, procreation has also provided a crucial occasion, pretext, and focus for the subordination of women to men in society. Many of the social disadvantages to which women have been subjected have been predicated upon their capacity for and role in childbearing. Although reproduction has a major impact

v. The Queen, No. 20835 (Can. S. Ct. filed June 1, 1988 and Oct. 26, 1988, and consolidated for argument) (LEAF factum in preparation on file with author), that Canada's statutory sexual history exclusion is supported by the sex equality guarantee of The Canadian Charter of Rights and Freedoms. Such an argument would also be relevant to cases like People v. Lucas, 160 Mich. App. 692, 408 N.W.2d 431 (1987), cert. granted, 111 S. Ct. 507 (1990) (No. 90-149) (challenging constitutionality of Michigan rape shield statute which permits judge to determine relevance of sexual history evidence in camera for purposes of admissibility).

124. This argument could potentially produce a different result in Florida Star v. B.J.F., 109 S. Ct. 2603 (1989).

125. See 136 CONG. REC. $\$ 8263$ (daily ed. June 19, 1990) (Violence Against Women Act) (creating federal civil cause of action for violation of civil rights through sexual assault or domestic battering when based on gender). Section 5 of the Fourteenth Amendment gives Congress authority to implement the Amendment's guarantees through legislation. Not entirely settled is the scope of this power as regards both private (as opposed to state) action and grounds for discrimination other than sex. Such a law fits within the very restrictive reading of the Civil Rights Cases, 109 U.S. 3, 25 (1883) ("If the laws themselves make any unjust discrimination, ... . Congress has full power to afford a remedy under that amendment and in accordance with it."). In Katzenbach v. Morgan, 384 U.S. 641 (1966), the Court stated, "Correctly viewed, $\S 5$ is a positive grant of legislative power authorizing Congress to exercise its discretion in determining whether and what legislation is needed to secure the guarantees of the Fourteenth Amendment." Id. at 651. Such authority would seem particularly clear where, as in the Violence Against Women Act, no conflict with state law is involved.

Most of the litigation examining the congressional authority to remedy equality violations between private parties has centered on interpreting congressional intent in situations of ambiguity as to whether a state party was envisioned or purely private conduct was also meant to be (or could be) reached. See Griffin v. Breckenridge, 403 U.S. 88 (1971) (Congress had authority to reach private conspiracies with section 1985(3) under Thirteenth Amendment and right to travel); Collins v. Hardyman, 341 U.S. 651 (1951) (predecessor to section 1985(3) only reached conspiracies under color of state law). Further, whether private conspiracies on bases other than race could constitutionally be reached under section 1985(3) has been left open by the Supreme Court. United Bhd. of Carpenters \& Joiners v. Scott, 463 U.S. 825, 836-39 (1983); Griffin, 403 U.S. at 102 n.9. Recent cases have interpreted section 1985(3) to apply to sex-based conspiracies. New York State Nat'l Org. for Women v. Terry, 886 F.2d 1339, 1358-59 (2d Cir. 1989); see also National Org. for Women v. Operation Rescue, 914 F.2d 582, 584-86 (4th Cir. 1990) (gender-based animus satisfies purposive discrimination requirement for purposes of section 1985 (3) claim). Thus, the constitutionality of new legislation expressly forbidding sex discrimination between two private parties in an area traditionally covered by state criminal law under the authority of section 5 of the Fourteenth Amendment would present a new, but not wholly uncharted, issue. See, e.g., Fitzpatrick v. Bitzer, 427 U.S. 445 (1976) (Congress has authority under section 5 of Fourteenth Amendment to prohibit sex discrimination in employment, including against states). Its resolution would likely turn on the extent to which the Court was persuaded that the injuries covered implicated Fourteenth Amendment equality values, and on the legislative record. There is no direct precedent in its way. 
on both sexes, men are not generally fired from their jobs, excluded from public life, beaten, patronized, confined, or made into pornography for making babies. This point is not the biological one that only women experience pregnancy and childbirth in their bodies, but the social one: women, because of their sex, are subjected to social inequality at each step in the process of procreation. Encompassed are women's experiences of "fertility and infertility, conception and contraception, pregnancy and the end of pregnancy, whether through miscarriage, abortion, or birth and child-rearing." ${ }^{126}$ As with most sex inequality, it is unclear whether an attribute distinctive to women is targeted for abuse and hatred because it is women's, or women are targeted for abuse and hatred because of a distinctive attribute. I suspect the former is closer to the truth. Either way, under male dominance, pregnancy, analyzed by Andrea Dworkin as "the primary physical emblem of female negativity,"127 and the potential . to become pregnant, are socially fundamental in women's inequality to men.

Grounding a sex equality approach to reproductive control requires situating pregnancy in the legal and social context of sex inequality and capturing the unique relationship between the pregnant woman and her fetus. The legal system has not adequately conceptualized pregnancy, hence the relationship between the fetus and the pregnant woman. This may be because the interests, perceptions, and experiences that have shaped the law have not included those of women. The social conception of pregnancy that has formed the basis for its legal treatment has not been from the point of view of the pregnant woman, but rather from the point of view of the observing outsider, gendered male. Traditionally, fetuses have not fared much better under this vantage point than have women. ${ }^{128}$ This may be changing at women's expense as increasingly, despite the explicit Supreme Court ruling to the contrary, ${ }^{129}$ the fetus becomes endowed with attributes of personhood. ${ }^{130}$ Men may more readily identify

126. Factum of the Intervenor Women's Legal Education and Action Fund para. 18, at 10, Sullivan and Lemay v. Regina, No. 21494 (Can. Sup. Ct. filed Feb. 22, 1989) (decision pending) (on file with author) [hereinafter LEAF's Sullivan and Lemay Factum].

127. A. DWORKIN, OUR BLOOD 100 (1976).

128. In the original case treating a fetus as a woman's body part, Oliver Wendell Holmes held in 1884 that a child could not recover for prenatal injuries because it was just a part of the mother at the time the injuries were sustained. Thus was the unity between the fetus and the pregnant woman affirmed as both of their harms were obscured. Dietrich v. Inhabitants of Northampton, 138 Mass. 14 (1884).

129. Roe v. Wade, 410 U.S. 113 (1973).

130. Cases creating fetal rights and attributing personhood to the fetus are encountered in the context of allowing wrongful death actions on behalf of stillborn fetuses, see, e.g., Commonwealth v. Cass, 392 Mass. 799, 467 N.E.2d 1324 (1984) (viable fetus is person for purposes of vehicular homicide statute); Vaillancourt v. Medical Center Hosp. of Vt., 139 Vt. 138, 425 A.2d 92 (1980) (statutory wrongful death liability exists for negligently caused death of viable fetus); of awarding custody of the fetus to others than the mother for purposes of forcing surgery, see, e.g., Jefferson v. Griffin Spalding County Hosp. Auth., 247 Ga. 86, 274 S.E.2d 457 (1981) (per curiam) (woman objected to performance of cesarean; court awarded temporary custody of fetus to Department of Human Resources and ordered woman to submit to surgery); and of prosecuting mothers for neglect for supplying harmful substances to their fetuses, see, e.g., In re Smith, 128 Misc. 2d 976, 492 N.Y.S. 2d 331 (N.Y. Fam. Ct. 1985) (fetus is person for purposes of New York Family Court Act and can be considered neglected child on basis of mother's drinking and failure to obtain prenatal care during pregnancy). For a discussion of the attempts to develop fetal legal rights and 
with the fetus than with the pregnant woman if only because all have been fetuses and none will ever be a pregnant woman. ${ }^{131}$

Accordingly, the law of reproductive issues has implicitly centered on observing and controlling the pregnant woman and the fetus using evidence that is available from the outside. The point of these interventions is to control the woman through controlling the fetus. ${ }^{132}$ Technology, also largely controlled by men, has made it possible to view the fetus through ultrasound, fueling much of the present crisis in the legal status of the fetus by framing it as a free-floating independent entity rather than as connected with the pregnant woman. ${ }^{133}$ Much of the authority and persuasiveness of the ultrasound image derives from its presentation of the fetus from the standpoint of the outside

personhood and how this intrudes upon the rights of pregnant women, see Gallagher, Prenatal Invasions \& Interventions: What's Wrong with Fetal Rights, 10 HARV. WOMEN's L.J. 9 (1987); Note, The Creation of Fetal Rights: Conflicts with Women's Constitutional Rights to Liberty, Privacy, and Equal Protection, 95 YALE L.J. 599 (1986). For a sex equality argument in the Canadian context opposing apprehension of a fetus by government for purposes of forcing a cesarean section, see Memorandum of Argument of the Women's Legal Education and Action Fund (Intervenor), Re Baby R., (1988) 30 B.C.L.R.2d 237 (S. Ct.) (No. A872582).

131. One interpretation of Freud suggests another reason: men might identify with the fetus as the embodiment of the penis, making abortion a symbolic castration. Freud thought that the baby was a penis to the woman and that women wanted penises. S. FREUD, Some Psychical Consequences of the Anatomical Distinction Between the Sexes, in 19 STANDARD EDITION OF THE COMPLETE PSYCHOLOGICAL WORKS OF SIGMUND FREUD 256 (J. Strachey trans. 1923-25) ("the equation 'penis-child" "). Luce Irigaray summarizes this aspect of Freud's analysis as follows: "The desire to obtain the penis from the father is replaced by the desire to have a child, this latter becoming, in an equivalence that Freud analyzes, the penis substitute." L. IRIGARAY, THIS SEX WHICH IS NOT ONE 41 (1985) (emphasis in original). If penis envy is regarded as a male construct, attributed to women and introjected by men, the baby, and prenatally the fetus, becomes a penis to men.

Reenvisioned as an insight into male psychology, and given that a woman's pregnancy and subsequent child are sometimes seen as proof of a man's potency, there may be something to the Freudian observation. Then again, the way the fetus can overtake the female may be better described as metaphysical. It would not be the first time that something less real that increases male power became invested with reality while something fully real that does not increase male power became deprived of it. In the end, as Kim Scheppele pointed out to me in the abortion context, the male capacity for abstraction may be more powerful than their capacity for identification with anyone who is not them.

132. See, e.g., In re A.C., 533 A.2d 611 (D.C. 1987) (denying motion to stay trial court's order authorizing hospital to deliver fetus by cesarean section from terminally ill woman without her consent), reh' $g$ granted and judgment vacated, 539 A.2d 203 (D.C. 1988) (judgment denying stay is vacated following operation and death of woman and fetus), on reh' $g, 573$ A.2d 1235 (D.C. 1990) (informed consent of woman or substituted judgment required to perform cesarean under such circumstances); MINN. STAT. ANN. $\S$ 626.556.1 (West 1990) (mandatory reporting and involuntary civil commitment of women who abuse drugs during pregnancy). But cf. Re Baby R., (1988) 30 B.C.L.R.2d 237 (S. Ct.); Re A. (in utero), (1990) 75 O.R.2d 82 (parens, patriae jurisdiction inadequate to force mother to have hospital birth because of impossibility of protecting child without forcing mother to undergo restraint and medical procedures against her will, possibly leading to "abuse of pregnant mothers"); Re F. (in utero), [1988] 2 W.L.R. 1288, 2 All E.R. 193 (unborn child cannot be ward of court because of difficulties enforcing order against mother). See also In re Troy D., 215 Cal. App. 3d 889, 263 Cal. Rptr. 869 (1990) (child born under influence of drugs due to mother's drug use while pregnant declared dependent of juvenile court; court would reject dependence petition in case of unborn fetus, however).

133. Factum of The Women's Legal Education and Action Fund (LEAF) para. 3, at 1, Borowski v. Attorney General for Canada, [1989] 1 S.C.R. 342 (No. 20411) (on file with author) [hereinafter LEAF's Borowski Factum]; Petchesky, Fetal Images: The Power of Visual Culture in the Politics of Reproduction, 13 FEMINIST STUD. 263 (1987). 
observer, the so-called objective standpoint, ${ }^{134}$ so that it becomes socially experienced in these terms rather than in terms of its direct connection to the woman. ${ }^{135}$ Presenting the fetus from this point of view, rather than from that which is uniquely accessible to the pregnant woman, stigmatizes her unique viewpoint as subjective and internal. This has the epistemic effect of making the fetus more real than the woman, who becomes reduced to the "grainy blur" at the edge of the image. ${ }^{136}$

The law of reproductive control has developed largely as a branch of the law of privacy, the law that keeps out observing outsiders. Sometimes it has. ${ }^{137}$ The problem is that while the private has been a refuge for some, it has been a hellhole for others, often at the same time. In gendered light, the law's privacy is a sphere of sanctified isolation, impunity, and unaccountability. It surrounds the individual in his habitat. It belongs to the individual with power. Women have been accorded neither individuality nor power. Privacy follows those with power wherever they go, like and as consent follows women. When the person with privacy is having his privacy, the person without power is tacitly imagined to be consenting. At whatever time and place man has privacy, woman wants to have happen, or lets happen, whatever he does to her. Everyone is implicitly equal in there. If the woman needs something-say, equality - to make these assumptions real, privacy law does nothing for her, and even ideologically undermines the state intervention that might provide the preconditions for its meaningful exercise. ${ }^{138}$ The private is a distinctive sphere of women's inequality to men. Because this has not been recognized, the doctrine of privacy has become the triumph of the state's abdication of women in the name of freedom and self-determination. ${ }^{139}$

Theorized instead as a problem of sex inequality, the law of reproductive control would begin with the place of reproduction in the status of the sexes. A narrow view of women's "biological destiny" has confined many women to

134. For further discussion of this as male, see C. MACKInNON, supra note 23, at 162-63.

135. From this perspective, killing the fetus on-screen produces fetal snuff pornography.

136. M. Eberts, Oral Argument in Borowski v. Attorney General for Canada before the Supreme Court of Canada (Oct. 4, 1988) (author attended argument).

137. See, e.g., Griswold v. Connecticut, 381 U.S. 479 (1965); Eisenstadt v. Baird, 405 U.S. 438 (1972); Roe v. Wade, 410 U.S. 113 (1973). Some early privacy cases in tort protected women from intrusive outsiders. See, e.g., Demay v. Roberts, 46 Mich. 160, 9 N.W. 146 (1881) (doctor invaded woman's privacy by bringing young man into her home while she was giving birth); see also Melvin v. Reid, 112 Cal. App. 285, 297 P. 91 (1931) (publication of film of former prostitute held impermissibly invasive). See generally A. Allen, UNEASY ACCESS (1988).

138. Webster v. Reproductive Health Servs., 109 S. Ct. 3040 (1989); Deshaney v. Winnebago County Dep't of Social Servs., 489 U.S. 189 (1989); Harris v. McRae, 448 U.S. 297 (1980).

139. This is discussed further in C. MACKNNON, supra note 23, at 184-94. See also a concurrence to the European Commission of Human Rights decision affirming the West German abortion decision requiring criminal restrictions on abortion in certain circumstances: "We are aware that the reality behind these traditional views [of abortion] is that the scope of protection of private life has depended on the outlook which has been formed mainly by men, although it may have been shared by women as well." Brlggemann and Scheuten v. Federal Republic of Germany, 3 E.H.R.R. 244, 256 (1977) (Opsahl, concurring, with Nørgaard and Kellberg). 
childbearing and childrearing and defined all women in terms of it, limiting their participation in other pursuits, especially remunerative positions with social stature. Women who bear children are constrained by a society that does not allocate resources to assist combining family needs with work outside the home. In the case of men, the two are traditionally tailored to a complementary fit, provided that a woman is available to perform the traditional role that makes that fit possible. Law has permitted women to be punished at work for their reproductive role. The option of pregnancy leave mandated by law was not even regarded as legal until recently; ${ }^{140}$ in the United States, it still is not required. When women begin to "show," they are often treated as walking obscenities unfit for public presentation. Inside the home, battering of women may increase during pregnancy. ${ }^{141}$ Pornography makes pregnancy into a sexual fetish, conditioning male sexual arousal to it, meaning targeting sexualized hatred against it. ${ }^{142}$ Whether or not women have children, they are disadvantaged by social norms that limit their options because of women's enforced role in childbearing and childrearing. For a woman who does become pregnant, these consequences occur even when a pregnancy is wanted.

Women often do not control the conditions under which they become pregnant; systematically denied meaningful control over the reproductive uses of their bodies through sex, it is exceptional when they do. Women are socially disadvantaged in controlling sexual access to their bodies through socialization to customs that define a woman's body as for sexual use by men. Sexual access is regularly forced or pressured or routinized beyond denial. Laws against sexual assault provide little to no real protection. Contraception is inadequate or unsafe or inaccessible or sadistic or stigmatized. Sex education is often misleading or unavailable or pushes heterosexual motherhood as an exclusive life possibility and as the point of sex. Poverty and enforced economic dependence undermine women's physical integrity and sexual self-determination. Social supports or blandishments for women's self-respect are simply not enough to withstand all of this.

After childbirth, women tend to be the ones who are primarily responsible for the intimate care of offspring - their own and those of others. Social custom, pressure, exclusion from well-paying jobs, the structure of the marketplace, and lack of adequate daycare have exploited women's commitment to and caring for children and relegated women to this pursuit which is not even considered

140. California Fed. Sav. \& Loan Ass'n v. Guerra, 479 U.S. 272 (1987).

141. Helton, McFarlane \& Anderson, Battered and Pregnans: A Prevalence Study, 77 AM. J. PUB. HeALTH 1337 (1987); R. Gelles, FAMILY VIOLENCE 126-34 (2d ed. 1987); R. GELLES, THE VIOLENT HOME 145-47 (1972); Hilberman \& Munson, Sixty Battered Women, 2 VICTMOLOGY 460, 462 (1977-78); Gayford, Wife Battering: A Preliminary Survey of 100 Cases, 1 BRIT. MED. J. 194 (1975). One researcher found that, of the wives in his sample who were assaulted, $23 \%$ were attacked while pregnant. Other researchers have recorded a range of $9 \%$ to $50 \%$ of battered women assaulted while pregnant. L. OXUN, WOMAN ABUSE 5152 (1986) (summarizing studies).

142. A. DWORKIN, PORNOGRAPHY 218-23 (1981). 
an occupation but an expression of the $\mathrm{X}$ chromosome. Women do not control the circumstances under which they rear children, hence the impact of those conditions on their own life chances. ${ }^{143} \mathrm{Men}$, as a group, are not comparably disempowered by their reproductive capacities. Nobody forces them to impregnate women. They are not generally required by society to spend their lives caring for children to the comparative preclusion of other life pursuits.

It is women who are caught, to varying degrees, between the reproductive consequences of sexual use and aggression on the one side and the economic and other consequences of the sex role allocations of labor in the market and family on the other. As a result of these conditions, women are prevented from having children they do want and forced to have children they do not want and cannot want because they are not in a position responsibly to care for them because they are women. This is what an inequality looks like.

Reproduction is socially gendered. Women are raped and coerced into sex. When conception results from rape or incest, it is a girl or a woman who was violated, shamed, and defiled in a way distinctively regarded as female. When a teenager gets pregnant because of ignorance or the negative social connotations of contraception, it is a young woman who is pregnant. When miscarriage results from physical assault, it is a woman who was beaten. When there is not enough money for another child or for an abortion, it is a woman who is forced to have a child she cannot responsibly care for. When a single parent is impoverished as a result of childbearing, usually that parent is female. ${ }^{144}$ When someone must care for the children, it is almost always a woman who does it, without her work being valued in terms of money or social status. Men, regardless of race, have not generally been sterilized without their knowledge and against their will, as have women of color. It has been held illegal to sterilize a male prisoner but legal to sterilize a mentally disabled woman. ${ }^{145}$ Those who have been defined and valued and devalued as breeders and body servants of the next generation are not usually men, except under circumstances recognized as slavery. The essential social function of nurturing new life has been degraded by being filled by women, as the women who fill it have been degraded by filling it. And it is women who, for reasons not always purely biological, may pay for giving birth with their lives.

In this context, the relationship between the woman, gendered female, and her fetus needs to be reconsidered. Although it hardly presents new facts, this

143. In an extreme instance of conditioning women's employment opportunities on the possibility of childbearing, the Johnson Controls Corporation's "fetal protection policy" excludes all "fertile" women from work where their exposure to lead in battery manufacture might affect a fetus through the placenta in the first weeks after conception. UAW v. Johnson Controls, 886 F.2d 871 (7th Cir. 1989), cert. granted, 110 S. Ct. 1522 (1990) (No. 89-1215).

144. Having children has been documented as a leading cause of poverty among women in Canada. CANADIAN ADVISORY COUNCIL ON THE STATUS OF WOMEN, WOMEN AND LABOUR MARKET POVERTY 7-35 (1990).

145. Compare Buck v. Bell, 274 U.S. 200 (1927) (mentally incompetent woman allowed to be sterilized) with Skinner v. Oklahoma, 316 U.S. 535 (1942) (male prisoner not allowed to be sterilized). 
relation has never been accorded a legal concept of its own. Because legal method traditionally proceeds by analogy and distinction, attempts at analogy between the relationship between the fetus and the pregnant woman and relations already mapped by law are ubiquitous. Had women participated equally in designing laws, we might now be trying to compare other relationships-employer and employee, partners in a business, oil in the ground, termites in a building, tumors in a body, ailing famous violinists and abducted hostages forced to sustain them-to the maternal/fetal relationship rather than the reverse. Sometimes there are no adequate analogies. As it is, the fetus has no concept of its own, but must be like something men have or are: a body part to the Left, a person to the Right. Nowhere in law is the fetus a fetus.

Considering the fetus a body part has been the closest the law has come to recognizing fetal reality and protecting women at the same time. Since men have body parts over which they have sovereignty, deeming the fetus to be "like that" has seemed the way to give women sovereignty over what is done to their bodies, in which the fetus inevitably resides. Because persons are sovereign, deeming the fetus to be a person, "like me," has seemed the way to take away women's control over it, hence over themselves. The body part analogy derives its credibility from the intricate and intimate connection between the fetus and woman. It derives nourishment from her and is accessible only through her. From before viability until fully completed live birth, the fetus is within the person of the woman and at one with her bodily systems. What happens to it happens to her and what happens to her happens to it-if not always in the same way. By telescoping the fetus into the woman, the body part analogy at once recognizes the unity of interest between fetus and pregnant woman that the personhood model is predicated on severing, and consolidates the woman as the decisionmaker for the unit.

Yet the fetus is not a body part. The fetus is ordinarily created through intercourse, a social relation through which impregnation occurs. Although some body parts are donated (as are some fertilized ova), no body part is created from a social relation-one between the sexes at that. Physically, no body part takes as much and contributes as little. The fetus does not exist to serve the woman as her body parts do. The relation is more the other way around; on the biological level, the fetus is more like a parasite than a part. The woman's physical relation to her fetus is expected to end and does; when it does, her body still has all of its parts. She is whole with it or without it; a miscarriage leaves her body as such intact, although the loss may diminish her. On the level of feeling, she has lost a part of her, but this is also true of loss of children who are fully born alive. Fetal dependence upon the pregnant woman does not make the fetus a part of her any more than fully dependent adults are parts of those on whom they are dependent. The fetus is a unique kind of whole that, after a certain point, can live or die without the mother. Whatever credibility the body part analogy has evaporates at the moment of 
viability, placing tremendous pressure on the viability line and its determination as a consequence. ${ }^{146}$ No other body part gets up and walks away on its own eventually.

The fetus is not even like gendered body parts. A fetus is lived by the pregnant woman through her pregnancy. A pregnancy is not, in fact or in social meaning, a body part, even a female body part. The cultural meanings of pregnancy are distinct. Pregnancy can be an emblem of female inferiority or adulation, of denigration or elevation; it can bring closeness or estrangement, can give a new sense of the meaning of life and new depth or desperation to the experience of family. It attracts violence against women, sentimentality, attempts at control, gives rise to financial costs and the need for difficult decisions. ${ }^{147}$ Women have lost jobs and been stigmatized and excluded from public life because they are pregnant-jobs and access they had in spite of having breasts and uteruses. It seems that it is one thing to have them, another to use them. ${ }^{148}$ No body part has the specific consequences pregnancy has on women's social destiny.

Now place the legal status of the fetus against the backdrop of women's tenuous to nonexistent equality. Women have not been considered "persons" by law very long; the law of persons arguably does not recognize the requisites of female personhood yet. Separate fetal status of any sort, in a male-dominated legal system in which women have been controlled through the control of their procreative capacity, risks further entrenchment of women's inequality. If the fetus were deemed a person, it may well have more rights than women do, especially since fetal rights would be asserted most often by men in traditionally male institutions of authority: progenitors, husbands, doctors, legislators, and courts. Fetal rights as such are thus in direct tension with sex equality rights.

Indeed, the only point of recognizing fetal personhood, or a separate fetal entity, is to assert the interests of the fetus against the pregnant woman. ${ }^{149}$ There would be two persons in one skin-hers-the rationale being that its life depends upon her, but the reverse is not usually true. The fetus could be given the right to the use of the pregnant woman's body from conception to birth. ${ }^{150}$

146. See Thornburgh v. American College of Obstetricians \& Gynecologists, 476 U.S. 747 (1986) (striking down provisions requiring doctors to report basis for nonviability conclusion as means of assuring any potentially viable fetus be born alive and mandating second doctor's presence at any abortion where fetus might be born alive); Webster v. Reproductive Health Servs., 109 S. Ct. 3040, 3061 (O'Connor, J., concurring), 3076 (Blackmun, J., concurring in part and dissenting in part) (1989); Colautti v. Franklin, 439 U.S. 379 (1979) (statute criminalizing doctors for neglect of viability, or possible viability, of fetus void for vagueness).

147. See LEAF's Sullivan and Lemay Factum, supra note 126, paras. 19-24, at 11-14.

148. A case like UAW v. Johnson Controls, 886 F.2d 871 (7th Cir. 1989), cert. granted, $110 \mathrm{~S}$. Ct. 1522 (1990) (No. 89-1215) collapses this distinction. See supra note 143. For an incisive analysis of the sex equality issues involved in "fetal vulnerability" policies, see Becker, supra note 76.

149. See supra note 130 .

150. This is the insight of Judith Jarvis Thompson's celebrated hypothetical. Thompson, $A$ Defense of Abortion, 1 PHIL. \& PUB. AFF, 47 (1971); see also Regan, Rewriting Roe v. Wade, 77 MICH. L. REV. 1569 (1979). 
In arguments for fetal personhood, the fetus is "born in the imagination."151 But it is not born in the world. Gestation and birth involve the mother and often entail considerable medical uncertainty. ${ }^{152}$ Even well toward the end of pregnancy, the view that the fetus is a person vaults over this process in a way that is unrealistic and dangerous for the birthing woman, who can be made invisible and chattel in a situation in which she is deeply implicated.

Personhood is a legal and social status, not a biological fact. As gestation progresses, the fetus grows from something that is more like a lump of cells to something that is more like a baby. As the body part analogy draws on the earlier reality to define the later one, the personhood analogy draws on the later reality to define the earlier one. In my opinion and in the experience of many pregnant women, the fetus is a human form of life. It is alive. But the existence of sex inequality in society requires that completed live birth mark the personhood line. If sex equality existed socially-if women were recognized as persons, sexual aggression were truly deviant, and childrearing were shared and consistent with a full life rather than at odds with it--the fetus still might not be considered a person but the question of its political status would be a very different one. 153

So long as it gestates in utero, the fetus is defined by its relation to the pregnant woman. This is why its status turns on her status. More than a body part but less than a person, where it is, is largely what it is. From the standpoint of the pregnant woman, it is both me and not me. ${ }^{154}$ It "is" the pregnant woman in the sense that it is in her and of her and is hers more than anyone's. It "is not" her in the sense that she is not all that is there. In a legal system that views the individual as a unitary self, and that self as a bundle of rights, it is no wonder that the pregnant woman has eluded legal grasp, and her fetus with her.

The legal status of the fetus cannot be considered separately from the legal and social status of the woman in whose body it is. The pregnant woman is more than a location for gestation. She is a woman, in the socially gendered and unequal sense of the word. In an analysis of women's status as socially disadvantaged, the woman is not a mere vehicle for an event which happens to occur within her physical boundaries for biological reasons. ${ }^{155}$ Women's

151. Mary Eberts created this characterization.

152. J. Katz, Maternal-Fetal Conflicts $45-48$ (Apr. 25, 1990) (unpublished manuscript on file with author).

153. On this issue, consideration of sex inequality would add a dimension to the perceptive analysis of comparative abortion laws provided by Mary Ann Glendon in her ABORTION AND DIVORCE IN WESTERN LAW (1987).

154. A. RICH, OF WOMAN BORN 64 (1976) ("The child that I carry for nine months can be defined neither as me nor as not-me.") (emphasis in original). Lynn Smith suggested stating Rich's definition in the affirmative.

155. The analysis of Sylvia Law gets no further than this in its consideration of gender in the abortion context, although it does consider the social consequences for women of being deprived of the abortion right in the context of a legal sex discrimination argument. Law, Rethinking Sex and the Constitution, $132 \mathrm{U}$. PA. L. REV. 955, 1016-28 (1984). 
relation to the fetus is not that of a powerful, fully capacitated being in relation to a powerless, incapacitated, and incomplete one. Indeed, it shows how powerless women are that it takes a fetus to make a woman look powerful by comparison. The relation of the woman to the fetus must be seen in the social context of sex inequality in which women have been kept relatively powerless compared with men. The fetus may have been conceived in powerlessness and, as a child, may be reared in powerlessness-the woman's. ${ }^{156}$ The effects of women's inequality in procreation can range from situations in which the woman does not choose to conceive but is forced to deliver to those in which the woman chooses to conceive and deeply desires to deliver but the baby dies.

The range of procreative events along which inequality is experienced contextualizes the fact that when women are forced into maternity, they are reproductively exploited. Short of achieving sexual and social equality-short of changing the context-abortion has offered the only way out. However difficult an abortion decision may be for an individual woman, it provides a moment of power in a life otherwise led under unequal conditions which preclude choice in ways she cannot control. In this context, abortion provides a window of relief in an unequal situation from which there is no exit. Until this context changes, only the pregnant woman can choose life for the unborn. ${ }^{157}$

Because the discussion of the political status of the fetus has been framed by the abortion controversy, it has proceeded from the premise that there is a

156. This is emphatically not to permit individual determinations of the balance of power in particular relationships as a predicate to granting a right to abort. The analysis here is of a political reality -women's subordinate status in society-that permeates, conditions, and transcends individuals and relationships. Laurence Tribe correctly points out that predicating the abortion right on individual determinations would be an invasion of privacy under existing law. L. TRIBE, ABORTION: THE CLASH OF ABSOLUTES 92-99 (1990); see also Massachusetts v. Secretary of Health \& Human Servs., 899 F.2d 53 (1st Cir. 1990) (state has no compelling interest in intruding into consultation between woman and her physician).

157. The consequences of this argument for abortion for sex selection purposes are not entirely clear to me but suggest that such practices should not be permitted. Selective abortion of female fetuses by state policy or encouraged or pressured by private entities would surely constitute sex discrimination-both against the woman's choice to bear a female child and, through her, against the gendered fetus. If fetal gender can be known for purposes of elimination, it should be able to be recognized for purposes of preservation. Most selectively aborted fetuses are female, in societies that denigrate and devalue women, see, e.g., India Makes Sure of Baby Boys, NEW SCIENTIST, Dec. 25, 1986-Jan. 1, 1987, at 8, and may also practice female infanticide and dowry murder, for example. The question is, should this recognition extend to official blocking of decisions by women to abort female fetuses? One state in India has restricted the practice of abortions for sex selection by law. Lingam, New Reproductive Technologies in India: A Print Media Analysis, 3 Issues IN REPRODUCTIVE \& GENETIC ENGINEERING 13, 18-19 (1990) (citing position taken by Indian Forum Against Sex Determination and Sex Pre-Selection, a nationwide umbrella organization in India); Weisman, No More Guarantees of a Son's Birth, N.Y. Times, July 20, 1988, at A1, col. 2. In addition to other costs, aborting female fetuses may further erode women's power as women make up less and less of the population. On the one hand, it is difficult to say why the reason for the abortion decision should matter until those who prescribe what matters live with the consequences the way the mother does, or until women can make such decisions in a context of equality. At the same time, in a context of mass abortions of female fetuses, the pressures on women to destroy potential female offspring are tremendous and oppressive unless restrictions exist. While under conditions of sex inequality monitoring women's reasons for deciding to abort is worrying, the decision is not a free one, even absent governmental intervention, where a male life is valued and a female life is not. 
conflict between what is good for the woman and what is good for the fetus. Sometimes there is. Usually there is not, in large part because when there is, women tend to resolve it in favor of the fetus. Women may identify with the fetus because, like them, it is invisible, powerless, derivative, and silent. ${ }^{158}$ Grasping this unity in oppression, it has most often been women who have put the welfare of the fetus first, before their own. While most women who abort did not choose to conceive, many women who keep their pregnancies did not choose to conceive either. The priority women make of their offspring may be more true in the abortion context than it seems. Many women have abortions as a desperate act of love for their unborn children. Many women conceive in battering relationships; subjecting a child to a violent father is more than they can bear. ${ }^{159}$ When women in a quarter to a third of all American households face domestic violence, ${ }^{160}$ this motivation cannot be dismissed as marginal. Some women conceive in part to cement a relationship which dissolves or becomes violent when the man discovers the conception. ${ }^{161}$ Even where direct abuse is not present, sex inequality is. Many abortions occur because the woman needs to try to give herself a life. But many also occur because the woman faces the fact that she cannot give this child a life. Women's impotence to make this not so may make the decision tragic, but it is nonetheless one of absolute realism and deep responsibility as a mother.

Reproduction in the lives of women is a far larger and more diverse experience than the focus on abortion has permitted. The right to reproductive control I have in mind would include the abortion right but would not center on it. Women would have more rights when they carry a fetus: sex equality rights. Women who are assaulted and miscarry, women who are forced to have abortions and women who are denied abortions, women who are sterilized, and women who are negligently attended at birth all suffer deprivation of reproductive control. Under such circumstances, existing laws that regulate these areas should be interpreted consistent with constitutional sex equality mandates. If affirmative legislative pursuit of this principle were desired, this concept of

158. Andrea Dworkin made this observation in a conversation with me.

159. See NCADV's Webster Brief, supra note 34 , at 2 . The same reality was highlighted by LEAF in Memorandum of Facts and Law Submitted by the Intervenor, The Women's Legal Education and Action Fund para. 58, at 16, Tremblay v. Daigle, [1989] 2 S.C.R. 530 (No. 21553), in which it was noted that Ms. Daigle stated Mr. Tremblay's violence against her contributed to her decision to abort.

160. R. DOBASH \& R. DOBASH, VIOLENCE AGAINST WIVES 14-20 (1979); L. WALKER, THE BATTERED WOMAN 19-20 (1979); Stark, Flitcraft \& Frazier, Medicine and Patriarchal Violence: The Social Construction of a Private Event, 9 INT'L J. HEALTH SERVICES $461-93$ (1979). See generally BUREAU OF JUSTICE STATISTICS, U.S. DEP'T OF JUSTICE, INTIMATE VICTIMS: A STUDY OF VIOLENCE AMONG FRIENDS AND RELATIVES (1980).

161. Carol Gilligan's discussion of women's abortion decisions, which include examples of such pressures, concludes that women reason morally in a way that is "different" from men. The discussion here suggests that sex inequality forces women to reason more relationally (inter alia) than men are required to do; specifically, women are forced to take men's views into account in a way that reflects the fact that men have social power. C. GILIGAN, supra note 55, at 106-27. For an evocative discussion of factors involved for women who confront abortions, see M. DENES, IN NECESSITY AND SORROW 91-127 (1976). 
reproductive control would encourage programs to support the fetus through supporting the woman, including guaranteed prenatal care, pregnancy leaves, and nutritional, alcohol, and drug counseling. If pursued in a context in which sexual coercion was effectively addressed, such programs would promote women's equality, not constitute inducements and pressures to succumb to women's subordinate roles. In this light, purported concern for the well-being of pregnant women and subsequently born children expressed by policing women's activities during pregnancy and forcing women to carry pregnancies to term is not only vicious and counterproductive, but unconstitutional. ${ }^{162}$

Because the social organization of reproduction is a major bulwark of women's social inequality, any constitutional interpretation of a sex equality principle must prohibit laws, state policies, or official practices and acts that deprive women of reproductive control or punish women for their reproductive role or capacity. Existing examples include nonconsensual sterilization, forced obstetrical intervention, supervision of women's activities during pregnancy under the criminal law, and denials of abortion through criminalization or lack of public funding where needed. Women's right to reproductive control is a sex equality right because it is inconsistent with an equality mandate for the state, by law, to collaborate with or mandate social inequality on the basis of sex, as such legal incursions do. This is not so much an argument for an extension of the meaning of constitutional sex equality as a recognition that if it does not mean this, it does not mean anything at all.

Under this sex equality analysis, criminal abortion statutes of the sort invalidated in Roe $v$. Wade violate equal protection of the laws. ${ }^{163}$ They make women criminals for a medical procedure only women need, or make others criminals for performing a procedure on women that only women need, when much of the need for this procedure as well as barriers to access to it have been created by social conditions of sex inequality. Forced motherhood is sex inequality. Because pregnancy can be experienced only by women, and because of the unequal social predicates and consequences pregnancy has for women,

162. This argument is made under the sex equality provision of the Canadian Charter of Rights and Freedoms in LEAF's Sullivan and Lemay Factum, supra note 126, paras. 11-27, at 8-15.

163. This is not to say that Roe should necessarily have been argued on sex equality grounds. Sex equality law was in its infancy at the time. But then privacy law barely existed either. It is to say that the real constitutional issue raised by criminal abortion statutes like that in Roe is sex equality and that it should be recognized as such. G. CALABRESI, IDEALs, BELIEFS, ATTTTUDES, AND THE LAW 87-114 (1985); L. TRIBE, supra note 156, at 105; Ginsburg, Some Thoughts on Autonomy and Equality in Relation to Roe v. Wade, 63 N.C.L. REV. 375 (1985); Schauer, Easy Cases, 58 S. CAL. L. REV. 399, 431 n.83 (1985); Strauss, Discriminatory Intent and the Taming of Brown, 56 U. CHI. L. REV. 935, $990-98$ (1989); Olsen, The Supreme Court, 1988 Term-Foreword: Unraveling Compromise, 103 HaRV. L. REV. 105 (1989); Sunstein, Why the Unconstitutional Conditions Doctrine is an Anachronism (With Particular Reference to Religion, Speech, and Abortion), 70 B.U.L. REV. 593, 616-20 (1990). The preamble to the East German Law on the Interruption of Pregnancy states that "[e]qual rights (Gleichberechtigung) of the woman in education and the professions, marriage, and the family requires that the woman herself can decide about pregnancy and whether to carry it to term." Gesetz liber die Unterbrechung der Schwangerschaft, GB1.I der DDR 89 (1972) (translated by author with Susanne Baer). 
any forced pregnancy will always deprive and hurt one sex only as a member of her gender. Just as no man will ever become pregnant, ${ }^{164}$ no man will ever need an abortion, hence be in a position to be denied one by law. On this level, only women can be disadvantaged, for a reason specific to sex, through state-mandated restrictions on abortion. The denial of funding for Medicaid abortions obviously violates this right. ${ }^{165}$ The Medicaid issue connects the maternity historically forced on African American women integral to their exploitation under slavery with the motherhood effectively forced on poor women, many of whom are Black, by deprivation of government funding for abortions. ${ }^{166}$ For those who have not noticed, the abortion right has already been lost: this was when.

Although the sex equality argument for equal funding is doctrinally simpler than that for the abortion right itself, statutes that recriminalize abortion ${ }^{167}$ would be invalidated under this argument. To recast the argument in a more doctrinal guise, statutes that draw gender lines are unconstitutional under the equal protection clause if they do not bear a valid or substantial relation to an important or legitimate and compelling state purpose. ${ }^{168}$ Initially, a state's purposes in passing criminal abortion statutes could be challenged as invalid. If states wanted to protect the fetus, rather than discriminate against women, they would help the woman, not make her a criminal. The most effective route to protecting the fetus-given illegal abortion, perhaps the only effective route-is supporting the woman. Further, the seeming appropriateness of forcing women to bear children when no such bodily impositions are made upon men by any state law-even after fetuses men have participated in creating become children (persons) and even when no alternatives are available-is transparently based on the view that the purpose of women is breeding. If using women as a sex as a means to an end is discriminatory, if naturalizing

164. This assumes that women will always gestate children in utero. If ways are found for men to gestate fetuses, obviously this would change. Extrauterine gestation would raise additional issues.

165. Medicaid funding for abortion has been upheld under a sex equality rubric in Doe v. Maher, 40 Conn. Supp. 394, 515 A.2d 134 (Conn. Super. Ct. 1986) (restriction of abortion funding to life-threatening situations violates, inter alia, state equal rights amendment). But cf. Fischer v. Department of Pub. Welfare, $85 \mathrm{~Pa}$. Commw. 215, 482 A.2d 1137 (1984) (restriction of abortion funding to life-threatening situations does not violate state equal rights amendment). The more usual theory is not strictly sex equality, but equal protection for indigent women, see, e.g., Committee to Defend Reproductive Rights v. Myers, $29 \mathrm{Cal}$. 3d 252,625 P.2d 779 (1981), or privacy.

166. See Harris v. McRae, 448 U.S. 297 (1980) (upholding Hyde Amendment restrictions on government funding of Medicaid abortions).

167. Guam recently passed an initiative to recriminalize all abortion "after implantation of a fertilized ovum" unless two doctors declare the mother's life or health to be at risk should she continue the pregnancy. The law criminalizes soliciting abortions, having them, and performing them. See Guam Soc'y of Obstetricians \& Gynecologists v. Ada, No. 90-00013, 1990 LEXIS 11910, at 3-4 (D. Guam Aug. 23, 1990) (quoting statute).

168. Mississippi Univ. for Women v. Hogan, 458 U.S. 718, 724 n.9 (1982); Personnel Adm'r of Mass. v. Feeney, 442 U.S. 256, 273 (1979); Craig v. Boren, 429 U.S. 190, 197 (1976). The related argument could also be made that such statutes do not bear a rational relation to a valid state purpose. See Reed v. Reed, 404 U.S. 71, 76 (1971). 
as destiny a role that is rooted in the history of sex inequality is discriminatory, the state purpose in restricting abortions is discriminatory and not valid.

But even assuming the state purpose were found valid-the purpose was not to harm women but to help fetuses, and this need not be pursued in the best way but only nonpretextually-the issue would remain whether such a statute were based on sex. Criminal abortion laws hurt women through a biological correlate of femaleness and a socially defining characteristic of gender long used to disadvantage women and keep them in a subject status. For this reason, criminal abortion statutes should be treated as closer to facially discriminatory than to neutral distinctions disparate in effect. By analogy, sexual harassment is legally treated more like facial than disparate impact discrimination, even though it is not done by express law or policy. Certainly, more men are sexually harassed than are denied abortions. ${ }^{169}$ Criminal abortion laws hurt no men the way they hurt only women. They single out women exclusively. Criminalizing providers, which does affect men, is merely a pretextually gender-neutral means of accomplishing the same goal: depriving women and only women, by law, of relief from a situation of sex inequality which begins in unequal sex and ends in unequal childrearing. If such statutes are treated as facial, not neutral, it is unnecessary to prove that they discriminate intentionally.

If intent had to be proven, states would doubtless argue that criminal abortion statutes aim to help fetuses, not hurt women. But intent can be inferred from impact. ${ }^{170}$ No men are denied abortions, even if some doctors, regardless of sex, are made criminals for providing them. Such a statutory impact would be far more one-sided than, for example, the impact of veterans' preference statutes, which have been found to lack the requisite discriminatory intent because, although most of those benefited by them are men, many men-nonveterans-are also harmed. ${ }^{171}$ No men are damaged in the way women are harmed by an abortion prohibition. Even those who can be prosecuted are harmed for performing what is, in essence, a female procedure, a procedure only women need, with the clear aim of keeping women and only

169. Disparate treatment cases under Title VII and disparate impact cases under the equal protection clause require a showing of intent or purpose to discriminate before the behavior will be regarded as discriminatory. Facial cases under the equal protection clause do not. Sexual harassment is treated as if facial in the sense that no showing of purpose or intent to discriminate has been generally required even though the cases are not argued as Title VII disparate impact cases and otherwise better fit the differential treatment model. See, e.g., Katz v. Dole, 709 F.2d 251, 256 (4th Cir. 1983) (intent not specifically required as element of Title VII sexual harassment case). But see Huebschen v. Department of Health and Social Servs., 716 F.2d 1167, 1171 (7th Cir. 1983) (intent required in equal protection sexual harassment case); Bohen v. City of E. Chicago, 799 F.2d 1180 (7th Cir. 1986) (same).

170. Washington v. Davis, 426 U.S. 229,242 (1976). I oppose the intent requirement, as it focuses on mental state not consequences, on perpetrators not victims, and on individuals not members of groups. It requires perpetrators to know what they are doing and why. Most discrimination does not happen this way.

171. Feeney, 442 U.S. at 274-75; see also New York State Nat'l Org. for Women v. Terry, 886 F.2d 1339, 1359 (2d Cir. 1989) ("[B]ecause defendants' conspiracy [under section 1985(3)] is focused entirely on women seeking abortions, their activities reveal an attitude or animus based on gender."). 
women from access to it. Male providers can avoid liability by refusing to perform the procedure and be, as men, no worse off, while pregnant women who seek to abide by the law must continue the pregnancy, damaging them in a way that only women are or could be damaged.

Remaining as a barrier to this argument is the view that pregnancy, hence abortion, is implicitly not sex-based because no men get pregnant and are treated better. That is, there are no "similarly situated" men differently treated, so depriving women in this way cannot be sex discrimination. ${ }^{172}$ Considering reproductive control as a sex equality right directly challenges the "similarly situated" requirement. In the pregnancy area, the notion that one must first be the same as a comparator before being entitled to equal treatment has been deeply undermined, although it remains constitutional precedent. After the Supreme Court held under Title VII that discrimination based on pregnancy was not discrimination based on sex, ${ }^{173}$ Congress reversed this result by amending Title VII, requiring that discrimination based on pregnancy be recognized as discrimination based on sex. ${ }^{174}$ As of this amendment, a cardinal difference between the sexes became an invalid reason for disadvantaging women. ${ }^{175}$ The implications of this shift are considerable. Most disadvantages can be construed as, and therefore become, differences. ${ }^{176}$ The question is whether social disadvantages-like jail and deprivation of government funding-will be treated under the old model for biological differences, as not subject to equality law, or whether the new model, under which not even biological differences justify unequal social outcomes, will be applied.

Moving away from its earlier formalism in the pregnancy area, the Court has begun to interpret statutory sex equality mandates in light of substantive equality goals. In an early ruling construing the pregnancy discrimination amendment to Title VII, the Supreme Court reached out explicitly in dicta, to a degree that was legally unnecessary, to repudiate its former constitutional reasoning on pregnancy, seeming strongly to signal its readiness to abandon its view under the Fourteenth Amendment that pregnancy is not gendered. ${ }^{17}$ In a further Title VII ruling on pregnancy, the Court gave sex equality reasoning a strong pro-equality spin, holding that a state-mandated pregnancy leave was not sex discriminatory because it promoted women's equal access to the

172. Geduldig v. Aiello, 417 U.S. 484,496 n.20 (1974).

173. General Elec. Co. v. Gilbert, 429 U.S. 125 (1976).

174. Pregnancy Discrimination Act of 1978,42 U.S.C. \$ $2000 \mathrm{e}(\mathrm{k})$.

175. There is an express exception for abortion in the Pregnancy Discrimination Act: "This subsection shall not require an employer to pay for health insurance benefits for abortion, except where the life of the mother would be endangered if the fetus were carried to term, or except where medical complications have arisen from abortion . . .." Id.

176. See supra notes $69-78$ and accompanying text.

177. Newport News Shipbuilding \& Drydock Co. v. EEOC, 462 U.S. 669 (1983). Justice Rehnquist, author of Gilbert for the Court, dissented in Newport News, arguing that the majority had there in effect overnuled Gilbert. Id. at 686 (Rehnquist, J., dissenting); see also Nashville Gas Co. v. Satty, 434 U.S. 136, 141-42 (1977) (distinguishing Gilbert; policy of denying accumulated seniority to pregnant women violates Title VII, imposing on women a burden men do not suffer). 
workforce. ${ }^{178}$ Here the Court chose not to enforce gender neutrality where that would have meant invalidating or extending to men (via parental leave) a sex-specific reproductive benefit for women at work, noting that the consequence was neutral in the sense that, under the statute, "women, as well as men, [can] have families without losing their jobs."179 The Court has not since had occasion directly to consider the issue of whether pregnancy is gendered in the legal sense. ${ }^{180}$ Specifically, it has not confronted this question in the constitutional context since these newer developments in statutory sex equality law came into sharp conflict with its approach on the constitutional side. Adjudication of recriminalized abortion by state law could present such an opportunity.

Doctrinally, it is possible for criminal abortion statutes to be found sex discriminatory but nonetheless justified, for example, by the goal of protecting fetal life. Putting aside the question of whether sex discrimination should ever be justified, this inquiry would be the right context in which to balance fetal death from legal abortions with maternal death from illegal ones. ${ }^{181}$ We would learn a lot about how much a woman's life is worth, hence about the reality of equality for women, from the answer.

Because forced maternity is a sex equality deprivation, legal abortion is a sex equality right. "Women's access to legal abortion is an attempt to ensure that women and men have more equal control of their reproductive capacities, more equal opportunity to plan their lives and more equal ability to participate fully in society than if legal abortion did not exist." 182 Sex equality would be advanced if women were permitted to control sexual access to their bodies long before an unwanted pregnancy. Sex equality would be advanced if society were organized so that both sexes participated equally in daily child care. Sex equality would be advanced by economic parity between women and men. Equality for women would gain from racial equality. All these changes would overwhelmingly reduce the numbers of abortions sought. The abortion controversy would not be entirely eliminated, but its ground would shift dramatically.

Those who support the abortion right in the name of "a woman's right to control her own body" might start earlier, before women are pregnant, with the

178. California Fed. Sav. \& Loan Ass'n v. Guerra, 479 U.S. 272 (1987).

179. Id. at 289.

180. Harris v. McRae, 448 U.S. 297 (1980), could have provided this occasion, but the sex equality argument was not made.

181. Cates and Rochat estimate that the death-to-case rate for illegal abortions is approximately eight times greater than for legal abortions. Cates \& Rochat, Illegal Abortions in the United States: 1972-1974, 8 FAM. PLAN. PERSP. 86, 92 (1976); see also Binkin, Gold \& Cates, Illegal Abortion Deaths in the United States: Why Are They Still Occurring?, 14 FAM. PLAN. PERSP. 163, 165-66 (1982) (pointing to lack of funding, lack of providers or access to them, desire for privacy, fear, and ignorance as factors in illegal abortion deaths since 1974). The death rate from illegal abortions for women of color in New York City prior to the legalization of abortion was found to be substantially higher than that for white women. Gold, Erhardt, Jacobziner \& Nelson, Therapeutic Abortions in New York City: A 20-Year Review, 55 AM. J. PUB. HEALTH 964, 965 (1965).

182. LEAF's Borowski Factum, supra note 133, para. 54, at 17. 
issue of sexual access. If women are not socially accorded control over sexual access to their bodies, they cannot control much else about them. Those who think that fetuses should not have to pay with their lives for their mothers' inequality might direct themselves to changing the conditions of sex inequality that make abortions necessary. They might find the problem largely withered away if they, too, opposed sex on demand.

\section{III}

When a system of power is thoroughly in command, it has scarcely need to speak itself aloud; when its workings are exposed and questioned, it becomes not only subject to discussion, but even to change.

Kate Millett ${ }^{183}$

The first part of these reflections takes on the complacency of the view that women have rights when we do not; the second part stands against the luxurious cynicism that despairingly assumes women have no rights when we do, or could. Both expose some of the workings of a gendered system of power whose command is maintained in part through being unspoken. In the process of the analysis some broader implications for change in equality law and theory are suggested.

Inequality, as analyzed here, is not a bad attitude that floats in the sky but an embodied particular that walks on the ground. It is first concrete, historical, present, and material, only derivatively generic, and never abstract. Social inequality does not first exist in the abstract, in search of a basis or polarization or natural joint to carve or asymmetry to which to attach. It exists in the social reality of its particulars, such as the social dominance of men through which women are subjected. Sex equality as a norm comes into being through the resistance of women as a people to their subjection. The equality principle, in this approach, is properly comprised of the practical necessities for ending inequality in each of its real forms.

Such an analysis does not generate abstractly fungible categories. Inequality is not conceptually reversible, only concretely changeable. To be "similarly situated," a test which relies on and produces abstract counter-hierarchical comparisons as the essence of equality reasoning, thus cannot remain the threshold for access to equality guarantees. If inequality is concrete, no man is ever in the same position a woman is, because he is not in it as a woman. That does not mean a man cannot be recognized as discriminated against on the basis of sex. It does mean that it is no measure of virtue for an equality theory to accord the same solicitude to dominant groups as to subordinate ones,

183. K. MILLETT, SEXUAL POLMTCS 87 (1971). 
all the while ignoring who is who. ${ }^{184}$ If the point of equality law is to end group-based dominance and subordination, rather than to recognize sameness or accommodate difference, a greater priority is placed on rectifying the legal inequality of groups that are historically unequal in society, and less solicitude is accorded pure legal artifacts or reversals of social fortune. Although such a substantive interpretation is technically possible, indeed compelled, under existing law, the passage of an Equal Rights Amendment could help provide a political and textual basis for this rectification of constitutional emphasis.

Law furthering this equality norm would develop a new relation to society. In societies governed by the rule of law, law is typically a status quo instrument; it does not usually guarantee rights that society is predicated on denying. In this context equality law is unusual: social equality does not exist, yet a legal guarantee of equality does. If law requires equality, in a society that is structurally and pervasively unequal, and the social status quo were no longer to be maintained through the abstract equality model, then equality law could not even be applied without producing social change. For example, it is generally thought that nondiscrimination and affirmative action are two different things. Under the equality approach argued here, there is no difference between them. Equality law becomes a distinct species of law, in need of its own norms for its distinct relation to an unequal society.

One part of developing the jurisprudence of such law is creating new doctrine. Here, the laws of sexual assault and abortion are argued to constitute facially sex-discriminatory state action. While existing state action doctrine readily accommodates these obvious forms, and existing discrimination law provides a basis for this recognition, the larger implications of this exposed interface between the state and women's everyday lives suggests the need for more commodious notions of both discrimination and state action. On a continuum of examples, denial of access to abortion, the marital rape exclusion, failure to enforce laws against domestic violence, the mistaken belief in consent defense in rape, and state protection of pornography ${ }^{185}$ are all gendered acts of government. Are they facial discrimination? From the standpoint of a woman being injured by them, are they state action? If not, are the concepts gender biased?

These forms of discrimination look like much of it: perhaps less provably purposeful than the existing model for intentional, but far from facially neutral and massively disparate in impact, they show a supportive interaction between government permission or omission and male aggression. More explicitly invidious than the neutral, but less superficially intentional than existing

184. Useful texts urging an approach consistent with the one advanced here are Fiss, Groups and the Equal Protection Clause, 5 PHIL. \& PUB. AFF. 107 (1976), and Strauss, The Myth of Colorblindness, 1986 SUP. CT. REV. 99.

185. For an illustration of this last category of gendered law, see American Booksellers Ass'n v. Hudnut, 771 F.2d 323 (7th Cir. 1985), summarily aff'd, 475 U.S. 1001 (1986). 
requirements for motive, such discriminations have social markers of sex written all over them and would arguably happen very differently if the stance of the government were different. ${ }^{186}$ Such laws and practices are simply biased, their one-sidedness diagnosable from subordinate group disadvantage, provable from invidious social meaning and damaging material consequences. Failure to see the state's hand in these examples would miss much of the way law insinuates itself into social life, intruding on and structuring relations between the sexes, institutionalizing male dominance.

Equality approaches are often faulted as less powerful because inherently relative, while other approaches like liberty or security or privacy are thought more powerful because absolute. Existing absolutes have not proven particularly reliable; one suspects they are usually defined sub rosa in relative terms anyway. It is true that equality never entirely escapes the comparative, but substantive comparisons that recognize hierarchy and history pose few of the dangers that abstract Aristotelian comparisons do. Nor must the standard for comparison be conceded. Subordinate groups may challenge the dominant standard as a form of bias in itself. Equality allows critique of the social partiality of standards as well as opportunity to live up to existing ones. The contextual nature of the equality right seems to me a strength: what it seeks is always real, because it is real for someone. In one's zeal to make deeper change, it should not be overlooked that actually having the best any group currently has-for example, not being about to be raped at any moment-would be a big improvement for most of us.

I am told that sex equality is not a desirable approach to reproductive control because it has a sunset built into it. Even if we had equality, wouldn't women still need abortions? If sex equality existed, there would be no more forced sex; safe effective contraception would be available and the psychological pressures surrounding its use would be gone; whatever womanhood meant, women would need neither men nor intercourse nor babies to prove it; abortions for sex selection as now practiced would be unthinkable; the workplace would be organized with women as much in mind as men; the care of children would be a priority for adults without respect to gender; women would be able to support themselves and their families (in whatever form) in dignity through the

186. For an example in the racial context, consider the recent case upholding employment practices which one dissenting Justice, aptly in my view, described as "bear[ing] an unsettling resemblance to aspects of a plantation economy." Wards Cove Packing Co. v. Atonio, 490 U.S. 642, 664 n.4 (1989) (Stevens, J., dissenting). Justice Stevens and the three Justices who joined him in his dissent indicated that the facts did not exactly fit either Title VII's "disparate treatment" or its "disparate impact" model. See id. at 673-78 (citing International Bhd. of Teamsters v. United States, 431 U.S. 324, 339-40 n.20 (1977)). These two theories of discrimination find rough constitutional parallels in equal protection's distinction between facial classifications and facially neutral classifications invidiously applied. If a segregated workplace does not fit either of the two available legal tropes for discrimination, perhaps a more responsive model should be created. The original creation of the models in Teamsters explicitly stated they were not mutually exclusive and did not say they were exhaustive. Teamsters, 431 U.S. at 335-36 n.15; see also Wards Cove, 490 U.S. at $668 \mathrm{n}$.13. For an illuminating discussion of the Canadian concept of systemic discrimination, see Action Travail des Femmes v. C.N.R., [1987] 1 S.C.R. 114 (Dickson, C.J.). 
work they do. Now imagine the woman who is pregnant without wanting to be. True contraceptive failures would probably remain, as would fetuses with life-threatening disabilities, selective abortions (where too many fetuses in one uterus threatens the existence of all, the modern lifeboat situation), good old fashioned not paying attention (but without all its currently gendered determinants), and the like. The point is, the politics of abortion would be so dramatically reframed, and the numbers so drastically reduced, as to make the problem virtually unrecognizable. If authority were already just and body already autonomous, having an abortion would lose any dimension of resistance to unjust authority or reclamation of bodily autonomy. Under conditions of sex equality, I would personally be more interested in taking the man's view into account. ${ }^{187}$ The issue of the pregnant woman's nine-month commitment and risk would remain, and might have to be dispositive. The privacy approach might make more sense.

Given the pervasiveness of inequality, imagination is the faculty required to think in sex equality terms. What would it be like if women had power, knowing what women know? Even under present conditions for women, two women with power under existing law, Madam Justice Bertha Wilson of Canada and Justice Sandra Day O'Connor of the United States, have written highly evocative abortion opinions. They are marked, on my reading, by a distinctively nonabstract and nonappropriative empathy. Both woman and fetus are real in their minds at once. Madam Justice Wilson, joining an opinion that invalidated Canada's criminal abortion law, speaks eloquently of the woman facing the abortion decision, highlighting the need to take her point of view seriously: "It is probably impossible for a man to respond, even imaginatively, to [the woman's abortion] dilemma not just because it is outside the realm of his personal experience ... but because he can relate to it only by objectifying it ...." In the history of human rights, she sees "the history of men struggling to assert their dignity and common humanity against an overbearing state apparatus." The history of women's rights, by contrast, has been "a struggle to eliminate discrimination, to achieve a place for women in a man's world, to develop a set of legislative reforms in order to place women in the same position as men ... not to define the rights of women in relation to their special place in the societal structure and in relation to the biological distinction

187. This is properly rejected under current law and social conditions. See, e.g., Planned Parenthood v. Danforth, 428 U.S. 52, 69-71 (1976) (states cannot constitutionally give spouse veto power over woman's first-trimester abortion decision); Wolfe v. Schroering, 541 F.2d 523, 525-26 (6th Cir. 1976) (expanding Danforth to second trimester); Poe v. Gerstein, 517 F.2d 787, $794-96$ (5th Cir. 1975) (man's right outweighed), aff d, Gerstein v. Coe, 428 U.S. 901 (1976); Doe v. Rampton, 366 F. Supp. 189, 193 (C.D. Utah 1973) (individual right of woman can't be burdened by veto); Conn v. Conn, 526 N.E.2d 958 (Ind.) (refusal to reconsider Danforth's ruling that putative fathers may not interfere with women's abortion decisions), cert. denied, 488 U.S. 955 (1988); Tremblay v. Daigle, [1989] 2 S.C.R. 530 (no legal basis for putative father blocking abortion); Paton v. United Kingdom, 3 E.H.R.R. 408 (1980) (right to respect for family life does not give putative father right to be consulted on, or to make applications about, wife's intended abortion). 
between the two sexes." Reproductive control is properly "an integral part of modern woman's struggle to assert her dignity and worth as a human being." 188 In other words, it is a sex equality issue. Justice Wilson's decision also retains some state interest in fetal life.

Justice O'Connor is similarly alive to the predicament of the pregnant woman who needs an abortion yet is also unwilling to disregard the fetus, especially the potentially viable one. ${ }^{189}$ She has expressed serious doubts about Roe, but her vote alone has prevented its repudiation. ${ }^{190}$ Taken together, and interpolating what is unspoken from what is spoken, the views of these Justices could be seen to request an approach to abortion that values women unequivocally but does not trivialize fetal life. Why, they seem to be asking, must this life or death decision be, by law, in women's hands? Sex inequality is the answer.

Anticipating the full reach of the difference sex equality would make is another matter. The challenge of grounded thinking and keeping faith with silenced women means facing that we cannot know what women not unequal as women would want, how sexuality would be constructed, how law would relate to society, what form the state would take, or even if there would be one.

188. Morgenthaler v. The Queen, [1988] 1 S.C.R. 30, 172 (Wilson, J., concurring).

189. Webster v. Reproductive Health Servs., 109 S. Ct. 3040, 3058-64 (1989) (O'Connor, J., concurring in part and concurring in judgment).

190. Id. See also Justice O'Connor's decision in Hodgson v. Minnesota, 110 S. Ct. 2926, 2950 (1990), in which she stresses the dilemma of the neglected or abused girl seeking an abortion and the inadequacy of the state's procedures for addressing her need not to be required to notify her parents. 